\title{
Lakeside View: Sociocultural Responses to Changing Water Levels of Lake Turkana, Kenya
}

\author{
David K. Wright ${ }^{1} \cdot$ Steven L. Forman $^{2}$ • \\ Purity Kiura $^{3} \cdot$ Christopher Bloszies $^{4}$. \\ Amanuel Beyin ${ }^{5}$
}

(C) The Author(s) 2015. This article is published with open access at Springerlink.com

\begin{abstract}
Throughout the Holocene, Lake Turkana has been subject to drastic changes in lake levels and the subsistence strategies people employ to survive in this hot and arid region. In this paper, we reconstruct the position of the lake during the Holocene within a paleoclimatic context. Atmospheric forcing mechanisms are discussed in order to contextualize the broader landscape changes occurring in eastern Africa over the last 12,000 years. The Holocene is divided into five primary phases according to changes in the strand-plain evolution, paleoclimate, and human subsistence strategies practiced within the basin. Early Holocene fishing settlements occurred adjacent to high and relatively stable lake levels. A period of high-magnitude oscillations in lake levels
\end{abstract}

Electronic supplementary material The online version of this article (doi:10.1007/s10437-015-9185-8) contains supplementary material, which is available to authorized users.

David K. Wright

msafiri@snu.ac.kr

Steven L. Forman

Steven_Forman@baylor.edu

Purity Kiura

pue03@yahoo.com

Christopher Bloszies

chris.bloszies@gmail.com

Amanuel Beyin

abeyin1@gmail.com

1 Department of Archaeology and Art History, Seoul National University, 1 Gwanak-ro, Seoul 151-742, South Korea

2 Department of Geology, Baylor University, Waco, TX 76790, USA

3 Archaeology Section, National Museums of Kenya, P.O. Box 40658, Nairobi 00100, Kenya

4 Lettis Consultants International, 1981 N. Broadway, Suite 330, Walnut Creek, CA 94596, USA

5 Department of Anthropology, University of Louisville, Lutz Hall Room 228, Louisville, KY 40292, USA 
ensued after 9,000 years BP and human settlements appear to have been located close to the margins of the lake. Aridification and a final regression in lake levels ensued after 5,000 years BP and human communities were generalized pastoralists-fishers-foragers. During the Late Holocene, lake levels may have dropped below their present position and subsistence strategies appear to have been flexible and occasionally specialized on animal pastoralism. Modern missionary and government outposts have encouraged the construction of permanent settlements in the region, which are heavily dependent on outside resources for their survival. Changes in the physical and cultural environments of the Lake Turkana region have been closely correlated, and understanding the relationship between the two variables remains a vital component of archaeological research.

Résumé Tout l'Holocène, le lac Turkana a été soumis à des changements drastiques dans l'altitude des lacs et les stratégies de subsistance des gens utilisent pour survivre dans cette région chaude et aride. Dans cet article, nous reconstruisons la position du lac au cours de l'Holocène dans un contexte paléoclimatique. Mécanismes de forçage atmosphériques sont discutées afin de contextualiser les changements de paysage plus larges qui se produisent en Afrique orientale au cours des 12.000 dernières années. L'Holocène est divisé en cinq phases principales en fonction des changements dans l'évolution altitude du lac, paléoclimats et les stratégies de subsistance humains pratiqués dans le bassin. Premiers établissements de pêche de l'Holocène ont eu lieu à proximité d'altitude d'eau élevés et relativement stables. Une période d'oscillations de grande amplitude dans l'altitude du lac s'ensuit après 9000 années BP et les établissements humains semblent avoir été situé à proximité des marges sur le lac. Aridification et une régression finale du altitude des lacs s'ensuit après 5000 années BP et les communautés humaines sont généralisées éleveurs-pêcheurs-cueilleurs. Au cours de l'Holocène tardif, les altitudes des lacs pourraient avoir chuté en dessous de leur position actuelle et les stratégies de subsistance semblent avoir fait preuve de souplesse et de temps en temps spécialisé sur le pastoralisme des animaux. Postes de les missionaires et du gouvernement modernes ont encouragé la construction de colonies permanentes dans la région, qui sont fortement tributaires des ressources extérieures pour leur survivance. Les changements dans les environnements physiques et culturels de la région du lac Turkana ont été étroitement corrélés, et la compréhension de la relation entre les deux variables reste une composante essentielle de la recherche archéologique.

Keywords Lake Turkana $\cdot$ Holocene $\cdot$ Paleoclimatic reconstruction $\cdot$ Environmental archaeology $\cdot$ Agriculture $\cdot$ Pastoralism

\section{Introduction}

Lake Turkana hosts one of the longest records of human biological and behavioral evolution extending from the deep Pliocene to the present day (Barham and Mitchell 2008; Robertshaw 1995; Willoughby 2006). The region has experienced dramatic changes in its landscape, transitioning from a tropical forest into an arid grassland environment as faulting and rifting have changed the topography of the basin. Presently, as a hydrological sink in a primarily arid region, the lake continues to draw 
humans and a wide array of flora and fauna to its margins. For these reasons, it has been an important center of human technological achievements since the beginning of human adaptive radiation.

The Lake Turkana Basin is a critical gateway for the introduction of livestock into sub-Saharan Africa and for understanding African settlement and subsistence systems. Although the significance of Lake Turkana as an incubator of intensive foraging and early food production in Africa has been known for decades (for a full review of archaeological investigations, see Robbins 2006), the lack of decadal- to centennialresolution paleoenvironmental time series has hindered understanding of the effect of climate variability on human activities. Paleoclimatic studies from the 1980s attempted to resolve archaeological settlement patterns with a variable lake level (Butzer 1980; Butzer et al. 1972; Owen et al. 1982). However, the lack of precise geographic coordinates and the reliance on radiocarbon ages using mixed shells, bone apatite, or charcoal from archaeological sites to reconstruct lake levels, necessitate new data to clarify the position of the lake and possible paleoclimatic conditions during the Holocene (Bloszies et al. in press; Forman et al. 2014). Thus, previous models (Barthelme 1985; Bower 1991; Gifford-Gonzalez 1998; Marshall 2000; Marshall et al. 1984; Wright 2011, 2013) describing the transition from foraging to food production in eastern Africa are in need of refinement using higher resolution (e.g., centennial-scale) paleoenvironmental datasets. This contribution presents a reconstruction of Lake Turkana within the context of regional hydrological inputs implicated in $>50 \mathrm{~m}$ variability in lake level at subcentury timescales between 14,000 and 4,000 years ago.

In light of this extreme variability in lake level, it is appropriate to reevaluate the evidence of human habitation and migration within this critical corridor of food intensification in eastern Africa. Significant paleoclimatic changes occurred simultaneous to the transition from intensive fishing settlements in the Early Holocene, to mixed pastoralism/foraging in the Middle Holocene, to specialized, nomadic pastoralism in the Late Holocene and the historic period. Although primarily a review of published literature, unpublished archival data from the National Museums of Kenya (NMK) will also be presented. The data are contextualized within a paleoclimatic framework to understand the resilience and flexibility in risk mitigation undertaken throughout the Holocene. As modern people adjust to accelerating changes in climate during the Anthropocene, a better understanding is needed of traditional risk-mitigation responses and cultural resilience in the face of extreme ecological changes.

\section{Setting}

\section{Hydrology and Climatology}

Lake Turkana is a closed basin with an estimated annual evaporation rate that translates to an average fall in lake level of $2.3 \mathrm{~m} /$ year in the absence of hydrological inputs (Ferguson and Harbott 1982, p. 32). The Omo River delivers about $90 \%$ of the water input for Lake Turkana with the remaining discharge deriving from the Turkwel and Kerio rivers and ephemeral streams that surround the lake (Yuretich 1979). The mean annual precipitation within most of the catchment is $<250 \mathrm{~mm} /$ year (Källqvist et al. 1988; Nicholson 1996). 
Lake Turkana is currently a closed basin and is therefore a sensitive proxy for precipitation in northern and eastern Africa. Residing at the lowest elevational limit of a series of cascading, endoheric lakes within the East African Rift Valley, runoff from this catchment zone ultimately discharges into Lake Turkana until the water level rises to about $100 \mathrm{~m}$ above its current level. Once this threshold is achieved, Lake Turkana spills over into the White Nile River catchment. There are three main mechanisms for precipitation on the Ethiopian Plateau: (1) the summer monsoons (June-September), (2) anticyclonic tropical depressions from the southern Indian Ocean associated with the winter monsoons, and (3) convergence from the Red Sea which mainly affects the northern reaches of Ethiopia (Conway 2000). The East African Monsoon brings the majority of rain to the northeast quarter of the African continent and occurs twice per year with the migration of the Intertropical Convergence Zone (ITCZ).

Increased precipitation in eastern Africa and high lake levels between 14,000 and 4,000 years BP are inferred to reflect a more easterly position of the Congo Air Boundary (CAB; Bergner and Trauth 2004; Tierney et al. 2011, 2013). The CAB is a zone of convergence between Atlantic and Indian Ocean moisture sources where there is a precipitation maximum inferred to be affected by Northern Hemisphere precessional-forced insolation changes (Kizza et al. 2009; Nicholson 1996). Fluctuations in lake levels in eastern Africa have been connected to enhanced East African Monsoon activity with eastward migration of the $\mathrm{CAB}$, though Indian Ocean sources for precipitation cannot be discounted (Bloszies et al. in press; Forman et al. 2014; Junginger et al. 2014; Levin et al. 2009; Morrissey and Scholz 2014; Nicholson 1996; Tierney et al. 2011).

\section{Other Controls on Lake Turkana Hydrology}

Lake Turkana lies within the East African Rift of the Great Rift Valley, which extends from the Red Sea to southern Africa. The Turkana Basin is comprised of a series of half-grabens and accommodation zones which change in orientation along the axis of the rift (Dunkelman et al. 1988). The accommodation zones are characterized by structural highs and zones of oblique slip-faulting (Dunkelman et al. 1988). In addition, transverse and rift parallel faults have been detected, especially prominent along the western edges of the lake (Vétel et al. 2004). High-angle growth faults detected in seismic reflection profiles of the sediments in the lake indicate that the basin has remained kinematically active throughout the Holocene (Johnson et al. 1987; see also Melnick et al. 2012; Morrissey and Scholz 2014).

Postdepositional changes in the elevation of relict beaches have been attributed to rifting processes ongoing throughout the Holocene and isostatic processes associated with changes in water volume of the lake (Garcin et al. 2012; Melnick et al. 2012). From a study on South Island, Melnick et al. (2012) estimate that ground surface uplift during the Holocene occurs at 7.5-9.6 mm/year when tectonic activity and isostatic rebound are placed within elastic and thermomechanical models. The aggregate effect of these processes resulted in $\sim 20$ to $30 \mathrm{~m}$ of absolute elevation change in South Island throughout the Holocene relative to an arbitrary 0 datum (Melnick et al. 2012). However, South Island is located in the center of the rift zone and occupies one of the most kinematically active areas of the region (Dunkelman et al. 1988; Le Gall et al. 2005) and does not appear to be representative of other relict shorelines around Lake Turkana (Bloszies et al. in press; Forman et al. 2014). 


\section{Paleoclimate of the Turkana Catchment}

There has been significant variability in climate and hydrology of Lake Turkana during the Holocene (Fig. 2(a)) and the understanding of the timing and magnitude of these shifts has evolved over the last three decades. There is evidence for sustained water levels $<300$ m.a.s.l. from 22,000 until 12,000 years BP in Lake Turkana as recorded in seismic profiles of the lake (Johnson et al. 1987; Morrissey and Scholz 2014) and relict beach ridge sequences up to $\sim 100 \mathrm{~m}$ above present lake level (Brown and Fuller 2008). This period correlates to generally cooler- and drier-than-present conditions across equatorial and northern Africa associated with deglaciation of the northern latitudes and cooling in the North Atlantic Ocean (Berke et al. 2012b; Beuning et al. 1997; Braconnot et al. 2000; Gasse 2000; Gasse et al. 2008; Schefuß et al. 2011; Stager and Mayewski 1997; Tiercelin et al. 1988; Tierney et al. 2011).

By 12,000 years BP, a change in the hydrology of Lake Turkana occurs and numerous proxy studies show that the lake level remained above its present threshold for almost 7,500 years, although its relative position was variable therein. Analysis of diatomaceous silts from the Koobi Fora Formation indicates Early Holocene ( $\mathrm{ca}$. $<12,000$ to 8,000 years BP) lake stands were +75 to $80 \mathrm{~m}$ above the 1976 lake level (Owen et al. 1982). Based on his research in the lower Omo River Valley, Butzer (1980) argues that Lake Turkana receded to its present elevation at 6,600 years BP, although Owen et al. (1982) question this assertion. Owen et al. (1982) argue that there were three phases of lake transgression with two high stands in the Middle to Late Holocene. Profound lake level drops are posited at $\sim 7,000$ and $4,000{ }^{14} \mathrm{C}$ years BP (7,800 and 4,500 cal. years BP) and a more gradual, but ultimately more severe drop in lake levels after 3,300 cal. years BP. However, the age models used in both Butzer (1980) and Owen et al. (1982) have been refined (Bloszies et al. in press; Forman et al. 2014; Garcin et al. 2012). Overflows of Lake Turkana into the Nile River may have occurred between 11,500 and 7,800 years BP and 7,400 and 4,300 years BP (Johnson and Malala 2009; see also Morrissey and Scholz 2014 in which Total Organic Carbon (TOC) derived from lake core sediments indicates overflow conditions between 10,000 and 6,000 years BP).

More recent sedimentologic analyses have employed new technologies and techniques to reconstruct prehistoric lake levels adjacent to Lake Turkana. Using a more comprehensive age model coupled with a detailed dGPS survey of shoreline deformation features, Garcin et al. (2012) argue for rapid drops in lake levels ca. 8,300 and 5,200 years BP with spillover, from the basin sill into the Nile River basin occurring $c a$. 11,000, 10,000-8,300, and possibly $c a$. 6,500 years BP. More recently, a detailed geomorphic and sedimentologic study of relict beach sequence in the Mt. Porr and Lothagam areas infer up to ten $20+\mathrm{m}$ century-scale oscillations in the level of Lake Turkana between ca. 14,000 and 4,000 years ago (Fig. 2(a); Bloszies et al. in press; Forman et al. 2014). In this reconstruction, generally pluvial conditions are inferred from 11,500 to 10,000 years BP followed by significant Middle Holocene lake level variability (Bloszies et al. in press). At least three spillover or near-spillover events are inferred dating to $c a$. 9,000, 6,200, and 5,000 years BP, each of which is bracketed by $30+\mathrm{m}$ transgressive-regressive phases in the lake elevation that occur on subcentennial timescales (Bloszies et al. in press). The final fall in lake level occurred ca. 5,000 years BP, when the lake began to lose significant amounts of water. By 
4,500 years BP, lake levels had dropped to within $20 \mathrm{~m}$ of its current elevation and did not rise above this level based on the presence of archaeological sites above $+20 \mathrm{~m}$ from the modern lake level (Bloszies et al. in press; Forman et al. 2014; Garcin et al. 2012). Smaller-scale oscillations in lake level are recorded in the past century as lake levels are $\sim 375$ m.a.s.l. at 100 years BP and fall $10+\mathrm{m}$ to present-day levels by about 50 years BP (Avery 2010; Källqvist et al. 1988).

\section{Paleoclimate of Adjacent Basins}

Geochronologies derived outside the Turkana Basin suggest enhanced monsoon activity during the Early Holocene across the western Indian Ocean, with significant spatial variability in monsoon precipitation beginning in the Middle Holocene. Presently, high monsoon activity in the western Indian Ocean is associated with warmer sea-surface temperatures (SSTs) and increased precipitation for the Turkana Basin (Bloszies and Forman 2015; Ummenhofer et al. 2009; Velpuri et al. 2012). Holocene climates were also modulated by the variable distribution of SSTs as well as zonal (Walker Cell) climate patterns. In the Gulf of Aden (Fig. 1(a)), deuterium isotopic values from terrigenous leaf waxes, an indicator precipitation within the Congo Basin $\left(\delta \mathrm{D}_{\text {wax }}\right)$ from an ocean sediment core, indicate variable but strong monsoon activity until $c a$. 5,000 years BP with an inferred weakening of monsoon-derived precipitation at $c a$. 4,500 years BP (Fig. 2(k); Tierney and deMenocal 2013). Off the Somali coast (Fig. 1(b)), reconstructed SSTs using alkenones are high in the Early Holocene and lower throughout the Middle Holocene, and express peak values between 5,500 and 3,800 years BP (Bard et al. 1997) although the data are sparse. Although Indian Ocean SSTs tied to monsoon strength are presently the main drivers of precipitation variability in the Turkana Basin as well as the rest of eastern Africa, the correlation between high SSTs and amplified monsoon activity is not linear, and secondary sources of moisture tied to zonal climate phenomena such as the Indian Ocean Dipole (IOD) can affect the level of Lake Turkana, but on meter scale (Bloszies and Forman 2015).

Lake Turkana lies within an extensive rift zone and is adjacent to a series of cascading basins that have significantly smaller catchments than Lake Turkana (Olaka et al. 2010). Relict shoreline analysis of the Suguta Valley (Fig. 1(c)), located to the immediate south with a transient connection to the Turkana Basin, detects the presence of a $300-\mathrm{m}$ deep lake $\left(390 \mathrm{~km}^{3}\right)$ periodically overflowing into Lake Turkana from 14,500 to 6,500 years BP (Fig. 2(b); Garcin et al. 2009; Junginger et al. 2014). Another transiently connected catchment to the north, Lake Chew Bahir (Fig. 1(d)) shows regressions in water levels from 12,800 to $11,600,10,800$ to 10,500 , and 9,800 to 9,100 years BP (Fig. 2(c); Foerster et al. 2012). Gradual, but progressively lower lake levels ensue from 8,000 to 7,500 years BP followed by an abrupt and severe regression associated with the termination of the African Humid Period (AHP) and onset of aridity after 7,000 years BP (Fig. 2(c); Foerster et al. 2012). Brief pluvial events are recorded at 3,000 and 2,000-1,300 years BP (Fig. 2(c); Foerster et al. 2012).

The termination of the AHP marks a period of progressive decline in rainfall across northeastern Africa; however, temporal and geographic expression of this phenomenon was variable. The diatom and oxygen isotope record extracted from Lake Ashenge (Fig. 1(e)), northern Ethiopia, shows overflow conditions from 7,600 to 5,600 years BP followed by an abrupt transition to arid conditions (Marshall et al. 2009). A sediment 


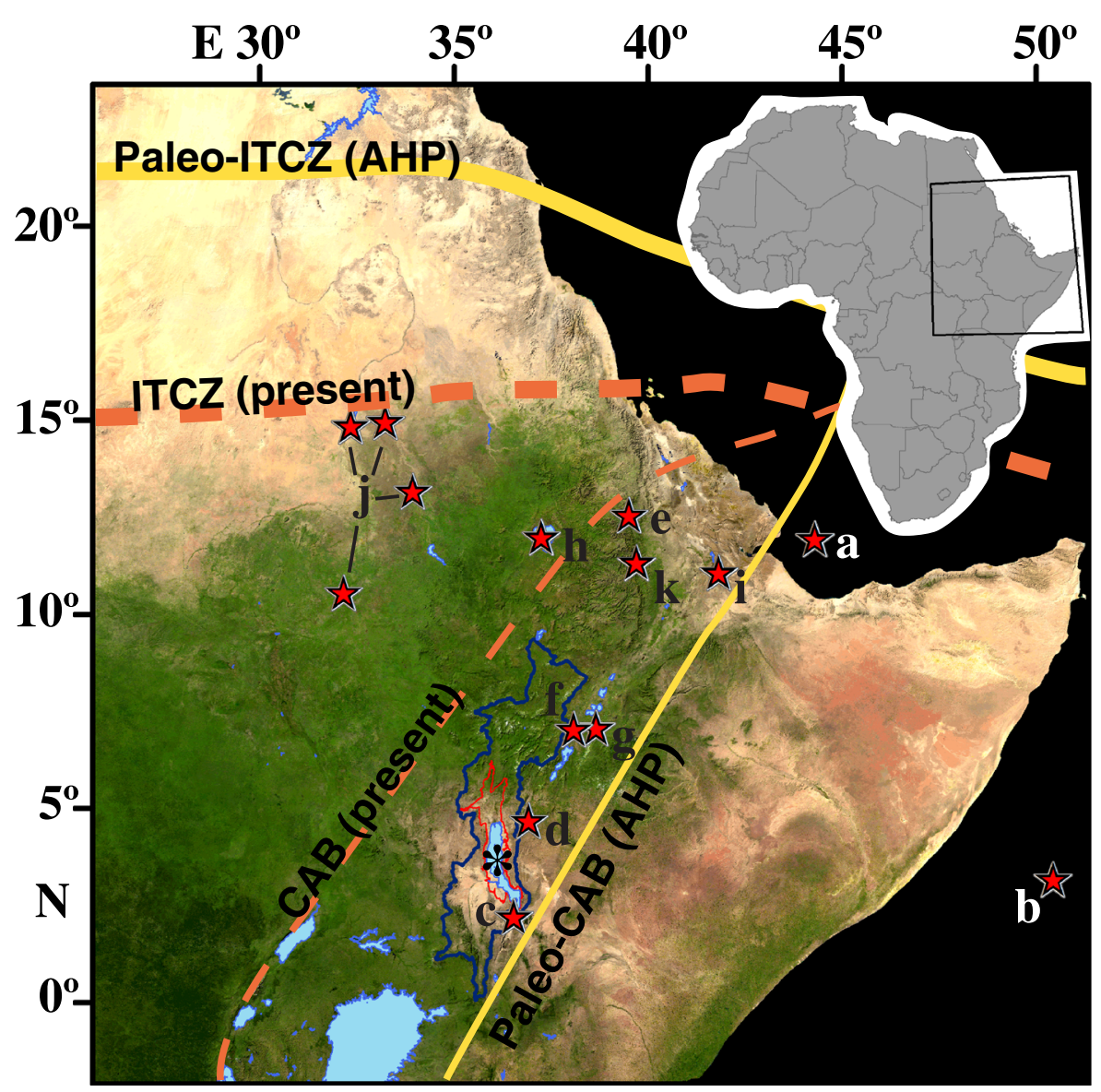

Fig. 1 Location of Lake Turkana (asterisk), the Turkana Basin (red outline), the Turkana Catchment (blue outline), and adjacent proxy records. Estimated northernmost positions of the ITCZ during the AHP and present day adapted from Junginger et al. (2014). a Gulf of Aden sediment core (Tierney and deMenocal 2013), $b$ Indian Ocean sediment core (Bard et al. 1997), c Paleolake Suguta (Garcin et al. 2009; Junginger et al. 2014), $d$ Lake Chew Bahir (Foerster et al. 2012), e Lake Ashenge (Marshall et al. 2009), $f$ Lake Tilo (Lamb et al. 2000), $g$ Lakes Ziway and Shala (Gillespie et al. 1983), $h$ Lake Tana (Costa et al. 2014; Marshall et al. 2011), $i$ Lake Abbe (Gasse and Van Campo 1994), $j$ Blue Nile sediment sources (Krom et al. 2002) and $k$ Lake Hayq (Lamb et al. 2007) (image in full color online)

core from Lake Tilo (Fig. 1(f)) in central Ethiopia records short periods of drying at $c a$. 8,400-8,800 and 6,700 years BP, with a permanent shift to aridity $c a$. 4,700 years BP (Fig. 2(d, e); Lamb et al. 2000). Less than $50 \mathrm{~km}$ to the north, two lakes with transient hydrological connections, lakes Ziway and Shala (Fig. 1(g)), show low stands sometime between 5,000 and 2,000 years BP (Fig. 2(f); Gillespie et al. 1983). Droughts are inferred from magnetic and geochemical data from cores extracted from Lake Tana (Fig. 1(h)) in the northern Ethiopian Highlands, centered around 8,400 and 7,500 years BP with progressive weakening of monsoon rains after 6,800 years BP (Fig. 2(g-i); Marshall et al. 2011). In another isotopic measure of moisture $\left(\delta D_{\text {wax }}\right)$ from the same lake core, the Early Holocene pluvial period ended $c a$. 8,500 years BP as conditions transitioned to a permanent xeric state (Costa et al. 2014). Maximum aridity is recorded ca. 4,200 years BP 


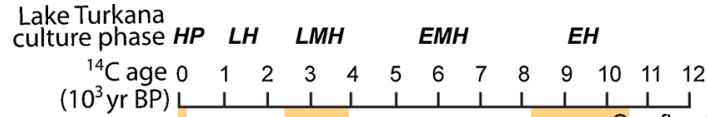

(a)

$\begin{array}{llllllllllll} & \left(10^{3} \mathrm{yr} B P\right.\end{array}$

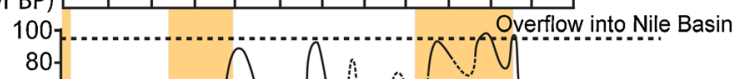

(c)

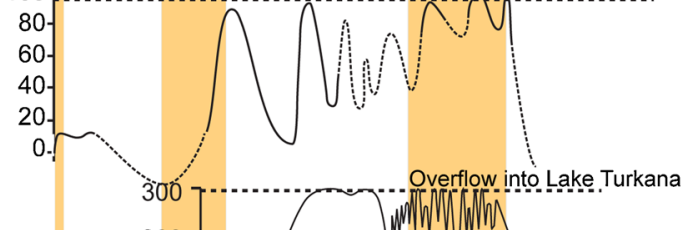

(b)

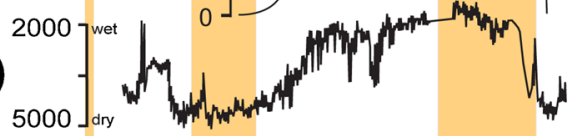

(d)
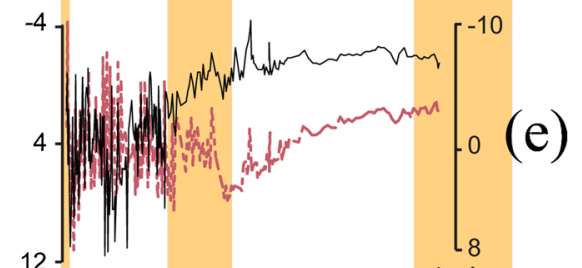

(f)

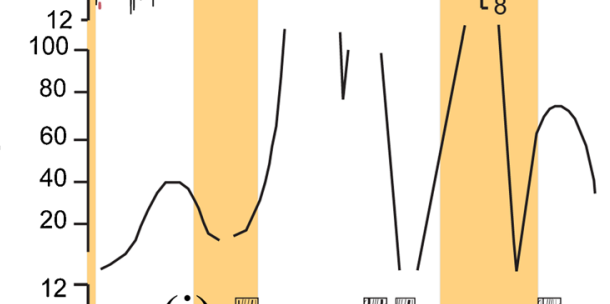

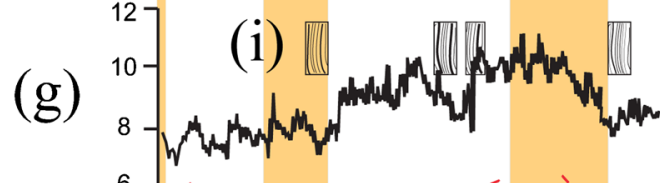

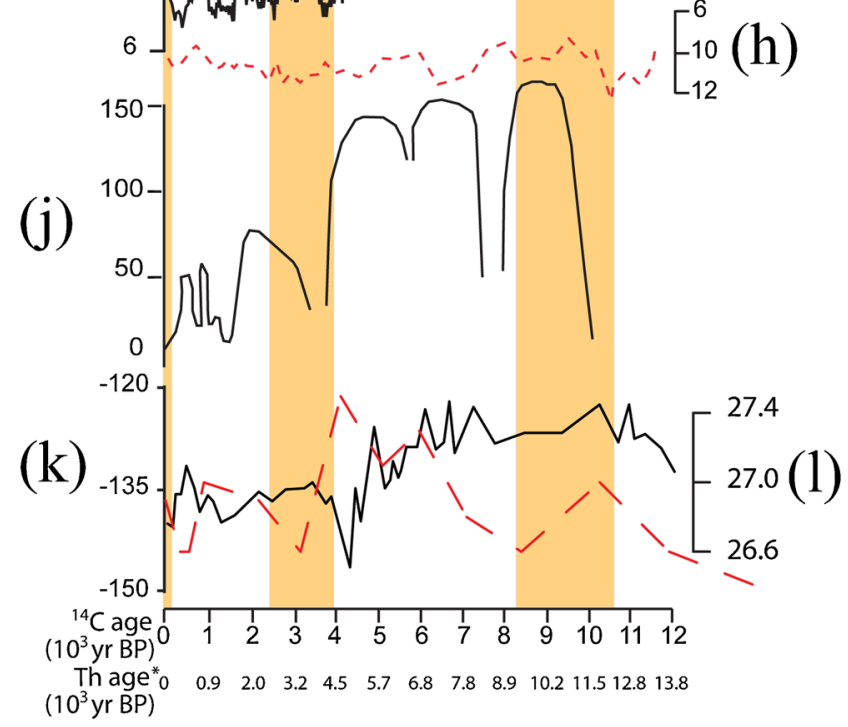


Fig. 2 Paleoclimatic proxies from northeastern Africa spanning the Holocene. $a$ Lake Turkana reconstructed lake level relative to 362 m.a.s.1. (Bloszies et al. in press; Forman et al. 2014); $b$ Paleolake Suguta reconstructed lake level relative to 570 m.a.s.l. (Junginger et al. 2014); c Lake Chew Bahir potassium (K) record (cps, Foerster et al. 2012); $d$ Lake Tilo $\delta^{13} \mathrm{C} \%$ VDB (solid line, Lamb et al. 2000); e Lake Tilo $\delta^{18} \mathrm{O} \%$ o SMOW (dotted line, Lamb et al. 2000); $f$ lakes Ziway-Shala-Abyata reconstructed lake level relative to 1636 m.a.s.l. (Gillespie et al. 1983); g Lake Tana titanium (Ti), modeled (mg/g) (solid line, Marshall et al. 2011); $h$ Lake Tana $\mathrm{X}_{\mathrm{ARM}} / \mathrm{X}_{\mathrm{LF}}$ (dashed line, Marshall et al. 2011); $i$ Lake Tana seismic unconformities (Marshall et al. 2011); $j$ Lake Abbe reconstructed lake level relative to 240 m.a.s.l. (Gasse and Van Campo 1994); $k$ Gulf of Aden $\delta \mathrm{D}_{\text {wax }}$ mean vs. Vienna standard mean ocean water (solid line, Tierney and deMenocal 2013); and $l$ MD85674 ocean sediment core reconstructed SSTs (dashed line, Bard et al. 1997). Asterisk, thorium ages calculated sensu Bard et al. (1990)

and a permanent lowstand at Lake Abbe (a.k.a. Abhé; Fig. 1(i)) is documented after 4,400 years BP (Fig. 2(j); Gasse and Van Campo 1994). These data correlate well with deep-water sediment cores from the Arabian Sea and Gulf of Aden showing progressive declines in monsoon strength after 5,500 years BP (Fig. 2(k); Overpeck et al. 1996; Tierney and deMenocal 2013), but are not completely synchronous.

The northern Ethiopian Highlands drain into the Blue Nile River lying to the immediate north of the Turkana Basin. High sedimentation rates and low flows in the Blue Nile (Fig. 1(j)) are documented from 5,650 to 4,750 and 2,050 to 1,000 years BP (Krom et al. 2002). An analysis of oxygen and carbon isotopes in carbonates and diatom assemblages from a sediment core from Lake Hayq (Fig. 1(k)), which is close to the western edge of the Rift Valley and immediately east of the Blue Nile drainage basin, detects wetter conditions between 700 and 1,300 years BP, separated by drier episodes (Lamb et al. 2007). However, this lake has remained relatively full throughout the last 2,000 years (Lamb et al. 2007) indicating varying hydrologic thresholds for lacustrine systems in northeastern Africa.

Fluctuating precipitation regimes across space and time in the paleoclimatic proxy record on the Ethiopian Plateau have been attributed to the eastern limit and precipitation delivery rates of the $\mathrm{CAB}$ during the Holocene (Bloszies et al. in press; Costa et al. 2014; Forman et al. 2014; Levin et al. 2009; Liu et al. 2003; Tierney and deMenocal 2013; Tierney et al. 2010, 2011). During the Early Holocene, the CAB has been inferred (Bloszies et al. in press; Costa et al. 2014; Forman et al. 2014; Junginger et al. 2014; Levin et al. 2009; Tierney and deMenocal 2013) to extend east of the Rift Valley from present-day Branched and Isoprenoidal Tetraether (BIT) isotopic data, providing a significant amount of summer rainfall (Tierney et al. 2011). Enhanced monsoon strength in the Gulf of Guinea (West Africa) and positive state of the IOD are attributed to a more easterly positioning of the $\mathrm{CAB}$ and higher rainfall across Lake Turkana, specifically (Morrissey and Scholz 2014), and eastern Africa, more generally (Tierney et al. 2011). Between 8,500 and 7,800 years BP, there are numerous proxy records across northern and equatorial Africa indicating low lake levels; however, most of the lakes are recharged at the end of this event (Gasse 2000). The exception to this appears to be in the northern portion of the Horn of Africa, where the termination of the AHP is earlier than in the southerly locations (Costa et al. 2014). This is likely the result of the $\mathrm{CAB}$ gradually migrating further west (Costa et al. 2014) which correlated with the progressively more southerly displacement of the ITCZ in the Middle Holocene (Barker et al. 2002; Thevenon et al. 2002). By 4,500 years BP, the final transition to more arid conditions was underway in the northern Rift (including the Turkana 
region) with periods of intensified monsoon activity providing exceptions to this trend and temporarily recharging lakes under more pluvial conditions (Berke et al. 2012a; Bloszies et al. in press; Costa et al. 2014; Forman et al. 2014; Levin et al. 2009; Tierney and deMenocal 2013; Tierney et al. 2010, 2011).

\section{Archaeological Evidence Within the Context of Regional Climatic Change}

Reporting of archaeological data from the Turkana Basin was not consistent or systematic prior to 1980. However, consistent curation of artifacts in the NMK in Nairobi has allowed archival research projects to integrate published and unpublished data to improve the resolution of data of Holocene communities in the Turkana Basin (Wright et al. 2014; Wright and Wright 2014). Archival data research involved systematic reanalysis and digital cataloguing of Holocene archaeological assemblages from the Turkana Basin in the NMK, digital photographing of decorated or temporally/culturally diagnostic artifacts, and plotting all site locations into a Geographical Information System (specifically, QGIS 2.0) with attribute data when possible. Unpublished site reports have also been transcribed or scanned and archived in the database. Herein, we access the full array of data available, to assemble as comprehensive a portrait as possible of cultural evolution in the Turkana Basin.

For the purposes of our discussion, we separate the Holocene occupation of the Turkana strand plain into five primary time periods based on the hydrologic evolution of the lake (Table 1). The Early Holocene (EH) covers the period from 12,000 to approximately 9,000 years BP when lake levels were relatively stable and high and people were engaged in specialized foraging practices. The Early Middle Holocene (EMH) begins after lake levels begin to significantly oscillate until approximately 4,500 years BP, when lake levels do not exceed $+20 \mathrm{~m}$ from their present elevations. The Late Middle Holocene (LMH) begins after the 4,500-years BP lake regression event when there is the first clear evidence for the introduction of domesticated animals into the region. The Late Holocene ( $\mathrm{LH}$ ) has evidence for significantly lower than present lake levels (beginning ca. 2,500 years BP) and dynamic population migrations in and out of the Turkana Basin. The Historic Period (HP) covers the period from 200 years BP when there is documentary evidence for lake regressions and the construction of missionary and aid distribution outposts in the Northern Frontier Province of colonial Kenya (later, Rift Valley and Eastern Provinces of postcolonial Kenya). The locations and summaries of attributes of known archaeological sites in the Turkana Basin are provided in the Supplementary Online Material (Table S1).

\section{Early Holocene, 12,000-9,000 Years BP}

Human settlement patterns in the Lake Turkana Basin are relatively well documented during the EH (Fig. 3a). This period correlates to a pluvial period distributed broadly across the northern two-thirds of the African continent (Castañeda et al. 2009; Gasse 2000). Similar to other locations throughout northern Africa (Hoelzmann et al. 2001; Kuper and Kröpelin 2006; Sutton 1977; Yellen 1998), settlement of the Lake Turkana region probably included low residential mobility and was focused on exploiting abundant aquatic resources (Barthelme 1985; Butzer 1980; Phillipson 1977; Robbins 
Table 1 Summary of culture phases for the Turkana Basin

\begin{tabular}{|c|c|c|c|}
\hline Time period (years BP) & Phase & Relative lake level & Cultural condition \\
\hline $12,000-9,000$ & $\mathrm{EH}$ & High & Lakeside fisher-foragers \\
\hline $9,000-4,500$ & EMH & Variable & $\begin{array}{l}\text { Probably dotted-wavy-line using pastoralists, } \\
\text { followed by Nderit Ware-using } \\
\text { namoratunga constructors }\end{array}$ \\
\hline $4,500-2,500$ & LMH & Low & $\begin{array}{l}\text { Initially, Nderit-using pastoralists, then } \\
\text { new forms of pottery; cairn burials; } \\
\text { some specialized pastoralists }\end{array}$ \\
\hline $2,500-200$ & LH & Lower than present & $\begin{array}{l}\text { Diverse modes of subsistence and } \\
\text { settlement }\end{array}$ \\
\hline 200-present & $\mathrm{HP}$ & $0-15 \mathrm{~m}$ above present & $\begin{array}{l}\text { High mobility pastoralism, fishing } \\
\text { communities, donor/aid supported } \\
\text { settlements }\end{array}$ \\
\hline
\end{tabular}

1974). Archaeological surveys of the Lake Turkana region suggest that there were at least seven major loci of EH settlement: (1) the Koobi Fora region in the northeast (Barthelme 1985), (2) Lowasera in the southeast (Phillipson 1977), (3) the Lothagam-Napadet Range (Robbins 1972, 1974), (5) the Kerio-Natome basin (personal communication [AB] with Robert Foley and Marta Lahr), (6) the Kalodir-Kapua Basin (Beyin 2011), and (7) the Omo River Delta/Kibish region in the northwest (Brown 1975; Butzer 1980). Riparian foragers with a more generalized subsistence and higher residential mobility patterns have also been identified from surrounding regions (Barthelme 1985, p. 277-278).

Stable highstands during the EH occurred against the backdrop of the evolution of specialized subsistence groups. A low-alkaline Lake Turkana and adjacent lakes (such as paleolakes Chalbi, Suguta, and Chew Bahir) were likely rich in aquatic resources,

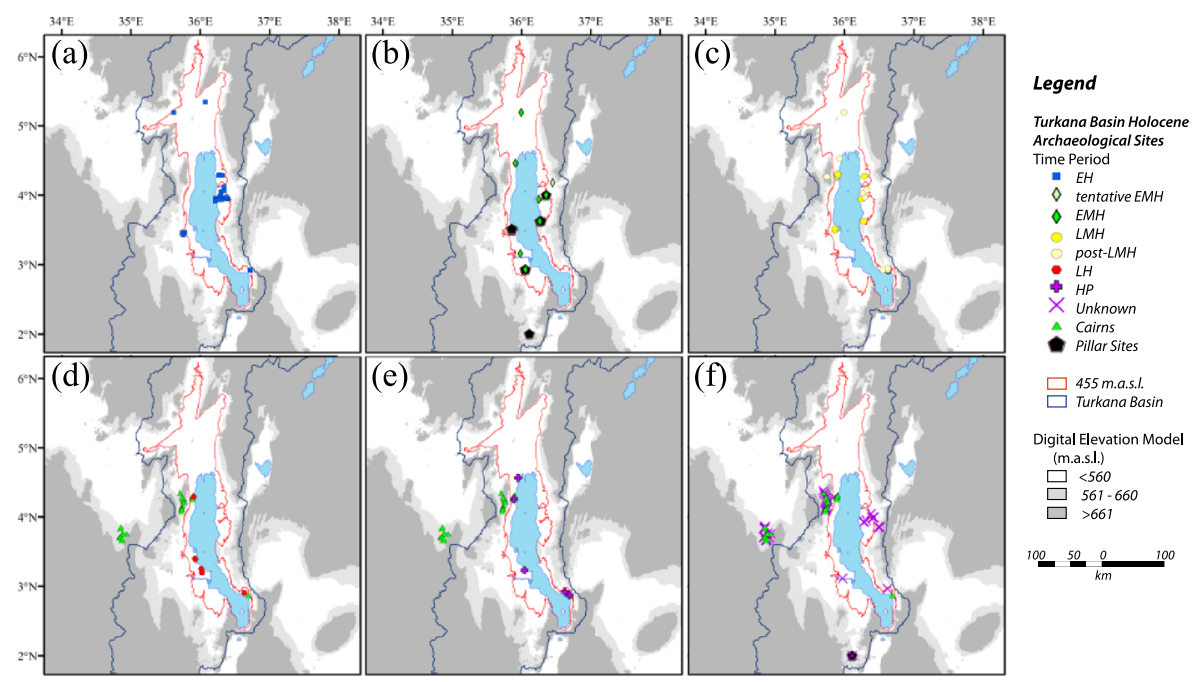

Fig. 3 Location of known archaeological sites in the Turkana Basin (see also Table S1). a EH, b EMH, c LMH and post-LMH, $\mathbf{d}$ LH and burial cairns, e HP and burial cairns, and $\mathbf{f}$ archaeological sites of unknown age (image in full color online) 
which people exploited (Stewart 1989). EH sites adjacent to lakes Ziway and Shala in the central Ethiopian Rift also include high proportions of fish in the faunal assemblages (Ménard et al. 2014). Fishing is presumed to have taken place using barbed bone points and cooking done in ceramic vessels (Fig. 4). High local precipitation levels also promoted denser stands of vegetation as evidenced by the recovery of closed-forest species in the archaeological faunal assemblages (Barthelme 1985; Phillipson 1977; Robbins 1974; Stewart 1989, p. 170).

Direct cultural affinities are difficult to establish between the inhabitants of the Turkana Basin and those of other "Aqualithic" communities in northern Africa. Obsidian analysis of artifacts from sites with barbed bone points (GaJj1 and Lowasera) indicates that raw materials for tools have a local provenance and are not coming from distant sources (Nash et al. 2011). The distribution of fishing communities in what is now the Sahara and Sahel using barbed bone points and wavy-line pottery suggests at least minimal transmission of subsistence technologies over vast areas (Stewart 1989; Sutton 1974, 1977; Yellen 1998). Such networks laid the foundation for what was to later transform the economy of sub-Saharan Africa when the ecosystem would no longer support fishing. However, regional technological variants abound such as at lakes Ziway-Shala, where the production of the "Ethiopian Blade Tool tradition" diverge, from known EH lithic traditions elsewhere in Africa (Ménard et al. 2014), suggesting localized adaptations to pluvial conditions.

\section{Early Middle Holocene, 9,000-4,500 Years BP}

This period begins with lake regressions in all local basins (Turkana, Chalbi, Suguta, Chew Bahir) potentially associated with cooler SSTs in the western Indian Ocean and weakening of the East African Monsoon (Bard et al. 1997; Tierney and deMenocal

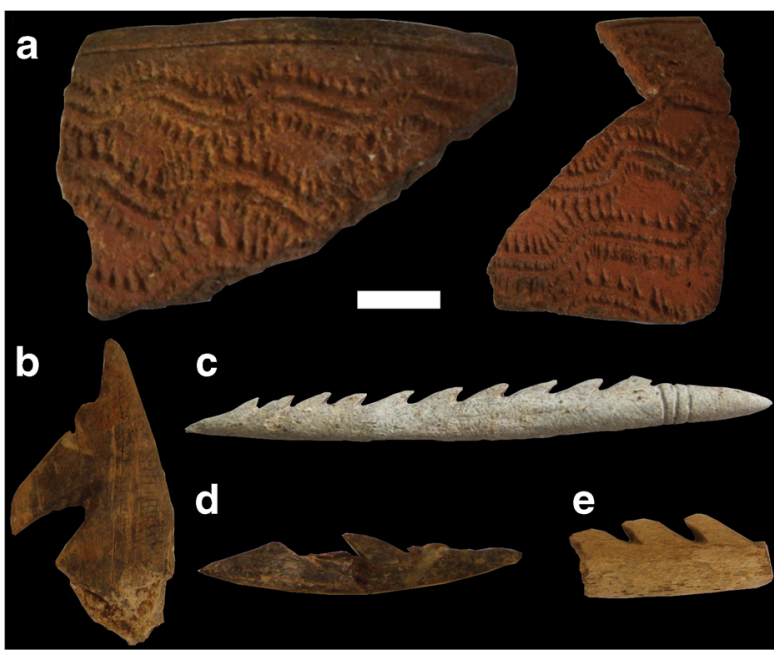

Fig. 4 a Dotted-wavy line pottery recovered from the ground surface adjacent to Eliye Springs. Provenience information documented in an unpublished report drafted by Alan Jacobs and hosted in the National Museums of Kenya, b subsurface uniserial barbed bone point from GcJh11 (Kokito 01; Beyin 2011), c uniserial barbed bone point from GeJi13 (Robbins 1974), and d-e surface collected uniserial barbed bone point from GcJh11 (Beyin 2011). White bar represents $1 \mathrm{~cm}$ (Photos: D. Wright) 
2013). The later phases of the EMH are marked by pronounced variability in the level of Lake Turkana above 370 m.a.s.l., although the potential for regressions below the present lake elevation is plausible (Fig. 2). Paleolakes Chalbi (Nyamweru 1989), Chew Bahir (Foerster et al. 2012; Golubtsov and Habteselassie 2010; Grove et al. 1975; Umer et al. 2004), and Suguta (Garcin et al. 2009; Garcin et al. 2012; Junginger et al. 2014) show concurrent desiccation, reflecting a change in local climate and a reduction in Omo River inflows. Later transgression phases inferred for Lake Turkana may have been part of a regional pluvial phase based on recharge of smaller water bodies in the southern Ethiopian Plateau (Lamb et al. 2000; Umer et al. 2004) and the northern Kenyan Highlands (Barker et al. 2001; Butzer et al. 1972; Hamilton 1982; Olago et al. 2000).

The variable location of the $\mathrm{CAB}$ and irregular distribution of monsoon rainfall across the Turkana Basin catchment during the EMH would have enhanced interannual uncertainty regarding the distribution of resources. Domesticated plants and animals appear in the Fayum region of northern Egypt by 7,400 years BP (Linseele et al. 2014) and domesticated cereals had been introduced from the Near East by 7,000 years BP in northern Sudan (Madella et al. 2014). Long-distance exchange networks across northeastern Africa from this period, accompanied by diverse subsistence strategies and nascent adoption of domesticates, suggest that cultural solutions to Middle Holocene climatic variability involved migrating between resource patches. Boattini et al. (2013; see also Fernández et al. 2007) argue that the mitochondrial DNA (mtDNA) of modern Afro-Asiatic (Cushitic) populations from eastern Africa supports the linguistic interpretation that ancestral population movements into eastern Africa from the Ethiopian Plateau began ca. 7,000 years BP (Ehret 1979). Likewise, Y-chromosome data support an expansion of Afro-Asiatic speakers out of their northeast African homelands 8,000 $\pm 2,500$ years BP with subsequent expansion across the northern periphery of central Africa and southward into equatorial Africa (Černý et al. 2009). Population movements associated with new pastoral economies were tethered to the edges of shrinking water bodies in the Sahara (Hoelzmann et al. 2001; Kuper and Kröpelin 2006) or, much later in time, following elevation gradients in the Ethiopian Highlands (Brandt and Carder 1987; Lesur 2007; Lesur et al. 2014) to secure fodder for their animals. Throughout the Horn of Africa, the adoption of domesticates appears to have occurred slowly and conservatively, with livestock being incorporated into local subsistence economies without radically transforming the fundamental technological or settlement structure of the region until much later in the Holocene (Lesur et al. 2014).

The lack of archaeological data in the Turkana region until after the EMH high lake stands suggests that two primary cultural phenomena were occurring. First, human settlement was likely closely restricted to the lake margins. Archaeological settlements are documented using charcoal or shell ages from the late regressive phase of Lake Turkana (ca. 5,000-4,500 years BP) in localities 102 and 103 in the Koobi Fora formation (Barthelme 1985, p. 22). There are few other securely dated EMH habitation sites situated on the shore margins based on depositional facies. GaJi4 is an early pastoral site with a recently generated radiocarbon age on charcoal of $4,180 \pm 40{ }^{14} \mathrm{C}$ years BP (4,580-4,840 cal. years BP, Beta-252053, Ashley et al. 2011), but is coeval with the final regression of Lake Turkana. Importantly, a charcoal age associated with an eroded human burial and barbed bone points at the "Lothagam Fishing Site" is $6,300 \pm 800{ }^{14} \mathrm{C}$ years BP (5,320-8,970 cal. years BP, UCLA-2124A, Robbins and 
Lynch 1978) and indicates that Aqualithic fishing traditions persisted in the region late into the EMH. In 2012, a radiocarbon age was analyzed on fish bones from the same depositional unit from which Robbins and Lynch's (1978) charcoal age was obtained and yielded an age of 5,515 $\pm 30{ }^{14} \mathrm{C}$ yr BP (6,280-6,400 cal. years BP, ISGS A-2348). Radiocarbon dates from sites within the Lothagam Hill area occur in the form of a charcoal age at $\mathrm{Zu}-10$ with a dating to $6,200 \pm 130{ }^{14} \mathrm{C}$ years BP $(6,790-7,415$ cal. years $\mathrm{BP}, \mathrm{N}-812$ ). These are reportedly associated with LSA microliths, a shell age from Zu-6 with decorated pottery and LSA microliths dating to $7,960 \pm 140{ }^{14} \mathrm{C}$ years $\mathrm{BP}(8,450$ 9,240 cal. years BP, N-813), and burned clay from Bb-14 located in the Lorungelup area with pottery and LSA microliths dating to 5,020 $220(5,310-6,285$ cal. years BP, N-814; Robbins 1972; Yamasaki et al. 1972, p. 237-238). Lawrence Robbins indicates in the research notes in the Radiocarbon article (Yamasaki et al. 1972) that N-813 stratigraphically agrees with a previously generated shell age of 7,560 $\pm 1,000(6,300-$ 11,070 cal. years BP, UCLA-1247E) from a "nearby" location (Yamasaki et al. 1972, p. 237-238). Site "P8" contains a fragmented human burial and hippopotamus remains with an associated shell age of $4,250 \pm 100{ }^{14} \mathrm{C}$ years BP $(4,450-5,250$ cal. years BP, L-1203-I), with eroded microliths and ceramic sherds that have no clear stratigraphic association with the in situ remains (Butzer 1980). Butzer (1980) and Owen et al. (1982) added a presumed reservoir effect to all of their radiocarbon ages of +400 years. Based on current available information, the presumed reservoir effect has been "uncorrected." Prior to the final transgression of the lake, near-shore settlement patterns left few traces in the archaeological record because sites were destroyed or deeply buried by littoral sediments by the oscillating lake level.

The second cultural phenomenon hypothesized from the available data is that residential mobility was probably relatively low and subsistence was focused on lacustrine resources. According to the results reported from Lothagam Hill (Robbins 1974; Yamasaki et al. 1972) and Kibish Plain (Butzer 1980), archaeological occurrences during the EMH were located on lacustrine or littoral deposits and appear to have been situated when the lake was close to the sites. The lack of evidence for EMH settlements outside the strand plain suggests continuity with the preceding EH settlement scheme of intensively occupied sites located adjacent to a water body, although there was likely a turnover in available fish species as lake salinity increased (Cerling 1979) and new interregional exchange networks evolved (Stewart 1989, p. 168-169).

Analysis of ichthyofaunal assemblages from EH sites in the basin shows that during the EH high stand, people focused on large fish such as Nile perch and cichlids (Stewart 1989). Stewart (1989) finds that with the retreat of the lake in the EMH, the diversity of exploited aquatic species increased and small fish dominated the human diet. On the basis of this observation, the initial use of pottery in eastern Africa may have arisen to cook small fish during the time when most large fish became scarce in the lake.

The ceramic data provide compelling evidence for the persistence or evolution of a regional cultural exchange network. The presence of dotted-wavy line pottery around the Turkana Basin in association with barbed bone points, formerly called "harpoons," has been published from EH-EMH deposits in Koobi Fora (Barthelme 1985) and wavy-line pottery at Lowasera (Phillipson 1977). Whether or not these finds are, in fact, dotted-wavy line/wavy-line traditions is highly speculative. A detailed, unpublished report made by Alan Jacobs in 1972 of dotted-wavy line and wavy-line ceramics from a 
surface collection made in the Eliye Springs area describes structural, decorative, and compositional features of sherds that associate them with the Khartoum Mesolithic (see also Fig. 4), but all of these identifications and conclusions require careful scrutiny. If confirmed, this is a likely extension of the bone-point (Aqualithic) traditions distributed across Saharan Africa (Sutton 1974, 1977), which included dotted-wavy line and wavy-line ceramics and had more restricted residential mobility patterns (Hoelzmann et al. 2001; Kuper and Kröpelin 2006; Kuper and Riemer 2013). Dotted-wavy line pottery and barbed bone points have been previously associated with Nilo-Saharan (Nilotic) speakers (Ehret 1974, 1993; Haaland 1992, 1993), who maintained broad, regional exchange networks across northern Africa throughout the EMH (Barich 2002; Mohammed-Ali and Khabir 2003). By the end of the EMH, members of the AfroAsiatic (Cushitic) language family had expanded throughout northern Africa (Ehret 1974, 1998; Haaland 1992) replacing broad-spectrum foraging/fishing/animal husbandry with specialized forms of pastoralism in the Sahara (Barich 2002). However, in the Turkana Basin, specialized pastoralism did not emerge until much later (Barthelme 1985; Marshall et al. 1984) despite linguistic evidence suggesting that Cushitic speakers had arrived in the region (Ehret 1974, 1998). Thus, based on the scant available evidence during the early portions of the EMH, the Turkana Basin may have been an area where syncretic blending of Nilo-Saharan, Cushitic, and Khoi subsistence (and probably material/social) cultures occurred. As in the northern portions of the Horn (Lesur et al. 2014), there is no evidence to suggest that there was a rapid shift in the subsistence economy or radical change in the technology until the latest phase of the EMH in the Turkana Basin.

The appearance of monumental mortuary features known as namoratunga appear to have no direct cultural precedent elsewhere in Africa, but are widely distributed across the Turkana Basin at the end of the EMH (Grillo and Hildebrand 2013; Hildebrand and Grillo 2012; Hildebrand et al. 2011; Lynch and Robbins 1978, 1979; Nelson 1995). Insomuch as archaeological traditions can show diachronic culture changes, these sites appear qualitatively distinct from their known antecedents. Namoratunga are comprised of compound human burials of which many individuals possess ornamental grave goods made from ostrich eggshell and worked bone, semiprecious stones such as amazonite and carnelian, and ceramic zoomorphic figurines (Grillo and Hildebrand 2013; Hildebrand et al. 2014). Found on both east and west sides of the lake, namoratunga are interpreted as the remains of a single cultural group attesting to the presence of well-developed transportation and exchange networks at this time (Grillo and Hildebrand 2013). Grillo and Hildebrand (2013) argue that namoratunga sites are associated with the first herders in the basin, but the seemingly rapid appearance of both domesticated animals and elaborate mortuary features may reflect a preservation bias against sites that predate them due to the transgression of the lake between 6,000 and 5,000 years BP. In light of the profound plunge in the level of the lake between 5,000 and 4,000 years BP, namoratunga may represent a cultural response to maintain social solidarity through an ecologically challenging circumstance.

\section{Late Middle Holocene, 4,500-2,500 Years BP}

This period is marked low lake levels, not only in Lake Turkana, but throughout northern and equatorial Africa associated with the termination of the AHP (Fig. 2; 
Berke et al. 2012a; Gasse 2000; Kröpelin et al. 2008; Mayewski et al. 2004). In the Turkana region, the termination was abrupt, but the magnitude of the drop was within the scope of fluctuating lake levels that occurred during the EMH (Bloszies et al. in press; Forman et al. 2014). The difference between LMH and EMH conditions is that the mean position of the $\mathrm{CAB}$ made a final westward shift between 5,000 and 4,000 years BP, which resulted in diminished rainfall adjacent to the lake margins. Smaller adjacent lakes such as Chew Bahir (Foerster et al. 2012) and Suguta (Junginger et al. 2014) reflect the reduced localized rainfall as the region transitioned to more permanently xeric conditions.

Animal husbandry was present in the Lake Turkana region by at least 4,500 years BP by people making jars with elaborate impressions called Nderit Ware (Fig. 5; Barthelme 1985; Marshall et al. 1984). The construction of namoratunga ceased by this time (Grillo and Hildebrand 2013) and the Lake Turkana region's archaeological assemblages became diverse (Marshall et al. 1984, p. 126). The archaeological culture
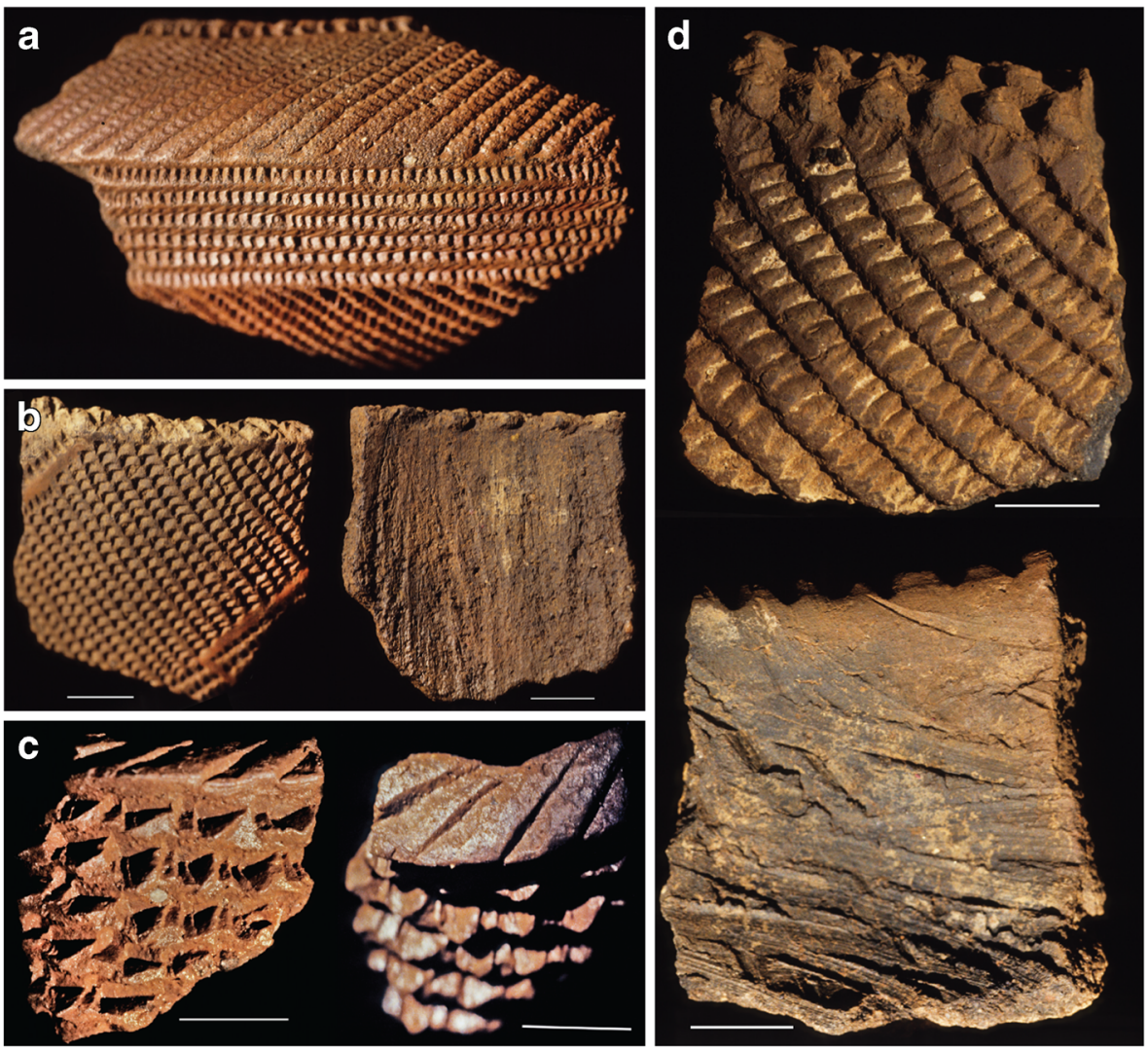

Fig. 5 Nderit Ware pottery from a Jarigole: shouldered bowl decorated with imbricated stylus impressions. b Jarigole: The pale strips of unimpressed surface have been painted in red and would have thus carried the major visual design on the vessel. The interior has been "brushed" vertically rather than scored, one of several techniques of interior "decoration." c Jarigole: evulsed stylus impressions with no burnishing or slip. Minimal temper inclusions are in the fabric of the ceramic. d Lothagam: carinated rim sherd of Nderit Ware with imbricated stylus impressions and a hounds tooth rim. White bars represent $1 \mathrm{~cm}$ (Photos: C. Nelson; more images and notes by Charles Nelson can be found at www.chaz.org) 
of these first herders is called the Pastoral Neolithic (PN), comprised of Afro-Asiatic speakers who kept domesticated animals and produced and used microlithic tools as well as the aforementioned ceramics (Bower 1991; Bower and Nelson 1978; Bower et al. 1977).

Initially, livestock was incorporated as an additional subsistence component within the broad-spectrum, riparian foraging regime that characterized EH and EMH settlements. One facet of the subsistence regime that clearly changed between the $\mathrm{EH}$ and the LMH is the near disappearance of barbed bone-point fishing techniques and exploitation of Nile perch. However, early PN settlements appear to have been restricted to the margins of the lake with no known archaeological settlements documented in the foothills or adjacent areas away from permanent water sources. The majority of artifact assemblages at LMH sites postdate 3,000 years BP and demonstrate that generalized subsistence strategies were practiced, including hunting and fishing, long after the appearance of specialized forms of pastoralism elsewhere in eastern Africa (Barthelme 1985; Robbins 1984; Wright and Forman 2011).

Another means that humans used to buffer themselves against environmental uncertainty was to develop cultural exchange networks. There are two primary lines of evidence to suggest that there was a robust interbasin cultural exchange system in operation from at least the LMH with potential deep roots in the EMH or EH. First, there are widely distributed ceramic traditions that suggest ongoing social interactions. Nderit tradition ceramics are virtually ubiquitous on PN sites from this time period (Wandibba 1981). Other vessel forms such as a distinct impressed coil jar with an orangish fabric found along the southeastern and western shores of Turkana (Fig. 6) are poorly dated, but their association with microliths on the strand plain that postdates the final regression of the lake strongly suggests a LMH provenience. Turkwel tradition ceramics occur during the late LMH and are also found across primarily on the western shoreline of the lake and finds of these artifacts extend into eastern Uganda (Fig. 7; Lynch and Robbins 1979; Robbins 1984). Second, analysis of obsidian analysis shows sustained trade in artifacts and raw materials across the lake, probably by the use of watercraft (Nash et al. 2011; Ndiema et al. 2011). The obsidian analysis shows the
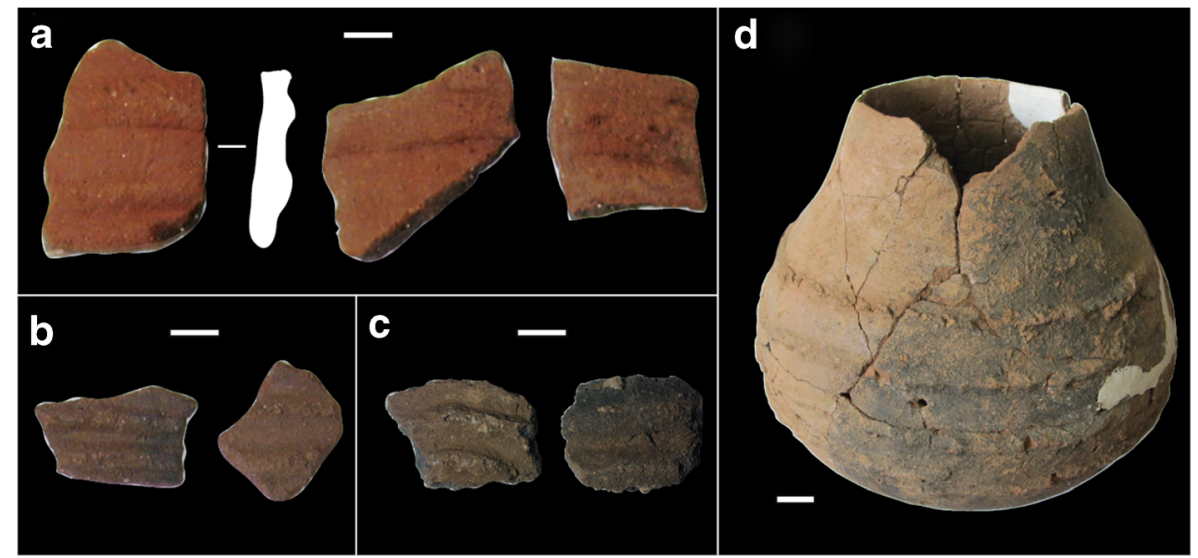

Fig. 6 Coil impressed ceramics from the Mount Porr region: a GeJk20, b GeJk22, c GeJk28 (Wright and Forman 2011), and d Kalenmuch Cairn (GbJd1d) collected by Robert Soper in 1980 at 2-12 cm below the ground surface. White bar in a-c represents $1 \mathrm{~cm}$ and in $\mathbf{d} 2 \mathrm{~cm}$ (Photos: D. Wright) 


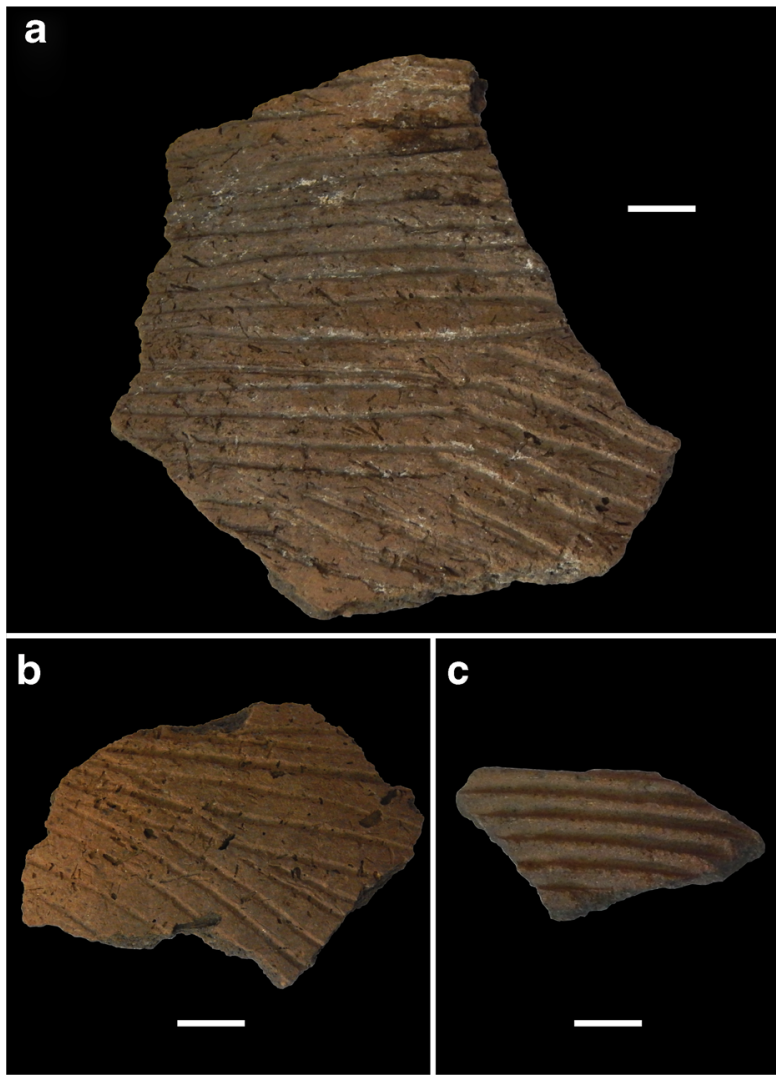

Fig. 7 Possible Turkwel pottery from Eliye Springs. All finds were collected from the ground surface by Lawrence Robbins and were curated in the National Museums of Kenya Archaeology Section. Note the different methods of scoring the exterior between $\mathbf{a}$ and $\mathbf{b}$ compared to $\mathbf{c}$. Sherds $\mathbf{a}$ and $\mathbf{b}$ also appear to be chaff tempered. White bars represent $1 \mathrm{~cm}$ (Photos: D. Wright)

lack of cultural barriers inhibiting the movement of specific materials across ethnic or language divides. Lake Turkana was the incubator of early livestock herding cultures of equatorial and southern Africa (Bower 1991, 1996; Gifford-Gonzalez 1998, 2000; Wright 2011), and the archaeological and social histories of the region attest to a long legacy of sustained cultural syncretism.

The spread of domesticated animals did not advance in a significant way south of the Turkana Basin until after 3,000 years BP (Bower 1991; Gifford-Gonzalez 1998; Marshall 2000). The spatial distribution of obsidian artifacts identified from the region indicate that although there is evidence for wide ranging local exchange networks, there is virtually no evidence for the introduction of raw materials from the East African Highlands to the south or the Ethiopian Highlands to the north, where high quality and quantity obsidian sources are abundant (Nash et al. 2011). As the geographic expansion of food production stalled in Lake Turkana, the frontier entered a "consolidation phase." During consolidation phases of human frontier expansion, intensification and specialization of agricultural production techniques occurs (Alexander 1980; Lane 2004). This process was apparently slow in the Turkana Basin (lasting at least 
1,500 years) and involved sustained intercommunity cultural exchanges. The consolidation of animal husbandry techniques occurred against the backdrop of xeric conditions across eastern Africa.

\section{Late Holocene, 2,500-200 Years BP}

There are few data to constrain lake level between 4,000 and 200 years ago besides a sediment core extracted from the southeastern portion of the lake and seismic data (Halfman et al. 1992; Halfman and Johnson 1988; Morrissey and Scholz 2014). Seismic unconformities dated to approximately 2,300 years BP indicate that the lake may have been $40 \mathrm{~m}$ below its current level (Morrissey and Scholz 2014). The terrigenous pollen record from the lake core infers a local arid interval centered between 2,500 and 1,600 years BP (Mohammed et al. 1995). Inversely, more pluvial adapted taxa are abundant during the subsequent period spanning from 1,600 to 600 years BP (Mohammed et al. 1995), which dates to the inferred transgression of the lake based on TOC and Total Inorganic Carbon (TIC) assayed from the core (Morrissey and Scholz 2014). Charcoal from the archaeological site of Apaget 1 located at $9 \mathrm{~m}$ above the present lake level dates to $1,800 \pm 300{ }^{14} \mathrm{C}$ years $\mathrm{BP}(1,070-2,430$ cal. years BP, UCLA$2124 \mathrm{~K}$ ) with ages of $870 \pm 80{ }^{14} \mathrm{C}$ years BP (680-930 cal. years BP, UCLA-2124G), $950 \pm 80{ }^{14} \mathrm{C}$ years BP $\left(690-1,050\right.$ cal. years BP, UCLA-2124J), $1,100 \pm 80{ }^{14} \mathrm{C}$ years BP (800-1,240 cal. years BP, UCLA-2124H), and $1,375 \pm 125{ }^{14} \mathrm{C}$ years BP $(1,000-$ 1,540 cal. years BP, GX-5041) is reported from the site of Lopoy, which is $18 \mathrm{~m}$ above the lake level (Lynch and Robbins 1979; Robbins 1980, 1984). These archaeological data are the terminus post quem for the transgression of the lake during the LH.

Population movements and the advent of specialized food producers, some of whom relied on highly mobile transhumant pastoralism, are documented from this period. The site of Namoratunga I with a bone collagen date of $1,200 \pm 100{ }^{14} \mathrm{C}$ years BP $(940$ 1,290 cal. years BP, UCLA-21240; Soper 1982) is one such site interpreted as showing the presence of specialized pastoralists (Robbins 1984, p. 207). The archaeological evidence correlates to a loosely dated period when migrations of eastern Afro-Asiatic and eastern and western Nilo-Saharan speakers occurred into the basin from the north and east (Ehret 2011, p. 117-119; Schlee 1985; Spear and Waller 1993). MtDNA genetic analysis of 287 individuals from across Kenya, including Turkana, shows extensive admixture between East African communities sufficient to mask "genetic founders" of distinct populations (Castrì et al. 2008; see also Batai et al. 2013). Population movements and interregional exchange networks evolve in the context of the development of highly itinerant pastoralism in eastern Africa (Marshall 1990, 2000).

LH inhabitants of Turkana continued to utilize stone tools and ceramics, but archaeological sites after 3,000 years BP show diversity in settlement patterns. Robbins $(1980,1984)$ defines five primary late prehistoric subsistence economies from the west side of Lake Turkana: (1) specialized cattle herders who did not fish nor hunt wild animals, (2) lakeside fishers using thin-sided Akira pottery who probably kept domesticated livestock but did not hunt wild animals, (3) lakeside hunter/pastoralists who did not fish, (4) relatively sedentary lakeside fishers using thick-walled/grooved Turkwel pottery who kept livestock and did little hunting, and (5) sorghum cultivating agropastoralists who inhabited the Turkwel River riparian zone and exploited the 
annual lake level fluctuations. Robbins (1984) points out that these archaeological signatures are not necessarily inclusive of the total range of cultural diversity and subsistence options available or exploited by the late prehistoric inhabitants of the region (see also Mutundu 2010 for an ethnoarchaeological perspective on site faunal patterning in eastern Africa).

The lakeside site of Lopoy (radiocarbon dates provided above) is probably the beststudied LH site in the Turkana Basin and shows the resilience and flexible nature of settlement through the various phases of occupation. People continued to produce and heavily rely on stone and bone tools long into the East African Iron Age and subsistence was focused on shoreline resources (Robbins 1980). Two groups are presumed to have occupied the site: one with Akira ceramics in which people were primarily hunting and the other using Turkwel ceramics in which people were primarily subsisting by fishing (Robbins 1980). Midden deposits appear to show continuous, year-round occupation of the site for hundreds of years and indicate low residential mobility (Robbins 1980).

Our view is that these subsistence categories might reflect the general archaeological site types found across the basin, but subsistence is a flexible concept that people change when the environmental or cultural situation warrants it. Many modern pastoralists also raise crops to supplement their diets and many so-called farmers keep small numbers of livestock. Mace (1993) argues that agropastoral households throughout sub-Saharan Africa adopt different subsistence strategies based on yearly subsistence needs. When resources are scarce, households will concentrate on the most viable means of subsistence available to them at the time. Because every ecosystem is different, there is no consistent "fallback" that most households will adopt. Chance plays a large role in determining household "wealth," but this chance can be minimized if flexible farming and pastoral strategies are adopted (Mace 1993, p. 365). In areas that frequently experience rapid climate fluctuations, this can be an important strategy to minimize the risk of complete crop failure or herd decimation.

The case of Ele Bor near the eastern edge of the Turkana Basin provides such an example of shifting resource utilization strategies in the face of different environmental pressures. Holocene occupations of the Ele Bor Rockshelter extend from the EMH to the LH period (Phillipson 1984). Archaeofauna show the shifts in foraging and pastoral strategies from large-bodied to small-bodied species, reflecting the available biomass and reduced precipitation from 5,000 years ago to recent times (Gifford-Gonzalez 2003). The data do not show specialized subsistence pursuits, but reflect flexible resource acquisition as a means of adapting to different climate and vegetation pressures.

\section{Historic Period, 200-0 Years BP}

European exploration of the Lake Turkana area began in earnest when Count Samuel Teleki and Ludwig von Höhnel arrived at the lake in 1888 and named it after their benefactor, Austrian Crown Prince Rudolf (von Höhnel 1894). However, the "northern frontier" was encircled by European interests and proxy claims for decades preceding the physical arrival of explorers to the region (Parkingham 1991). The region was noted for its inhospitable climate, rugged terrain, and fierce populations and was never fully incorporated into either the British colonial or Kenyan postcolonial governance systems. Christian missionaries, the United Nations, nongovernmental organizations (NGOs), and the 
Kenyan government have constructed the most enduring infrastructure around the lake margins in the form of schools, churches, and aid distribution centers and have become critical fallback centers for the local populations during periods of resource stress.

The primary factor separating the HP from the preceding periods is the presence of a $100+$ year lake level curve based on gauges and altimeters. Critically, the data show the scale of lake level oscillations measured from ca. AD 1900 to 1955, and the lake dropped $20 \mathrm{~m}$ in absolute elevation (Butzer 1971, p. 123; Källqvist et al. 1988). Unfortunately, complementary rainfall data for the southern Ethiopian Highlands for the same period is unavailable and the scant records that exist are difficult to calibrate (Conway et al. 2004). In piecing together the fragmentary precipitation data that do exist using a singular value decomposition analysis to gridded rainfall data from southern Ethiopia, there does not appear to be a linear decline in precipitation that the lake level data would suggest (Jury 2010) indicating that Turkana lake levels are tied to more factors than southern Ethiopian precipitation alone (see Bloszies and Forman 2015 for a full discussion).

The Turkana word for the lake is anam ka'alakol or "lake of many fish," suggesting that aquatic resources have been important food resources for many centuries. However, the degree to which this resource was dependable certainly varied on water levels, which control salinity in the lake (Ferguson and Harbott 1982; Källqvist et al. 1988; Yuretich 1979; Yuretich and Cerling 1983). Large-bodied species, such as Nile perch, are high trophic organisms that are saline-tolerant, but they migrate into deeper waters following lower-chain species that are more sensitive to slight changes to the water's chemistry (Källqvist et al. 1988).

The diets of the modern inhabitants of the Lake Turkana region are specialized, reflecting intercommunity differences in settlement and subsistence practices. Stable isotope analyses conducted on modern populations living adjacent to Lake Turkana show clear divergences in dietary habits between ethnic communities (Kiura 2005). The three groups of people studied (Dassanetch, Elmolo, Gabbra) are clearly separated in their $\delta^{13} \mathrm{C}$ and $\delta^{15} \mathrm{~N}$ values, reflecting their drastically different diets (Fig. 8). However,

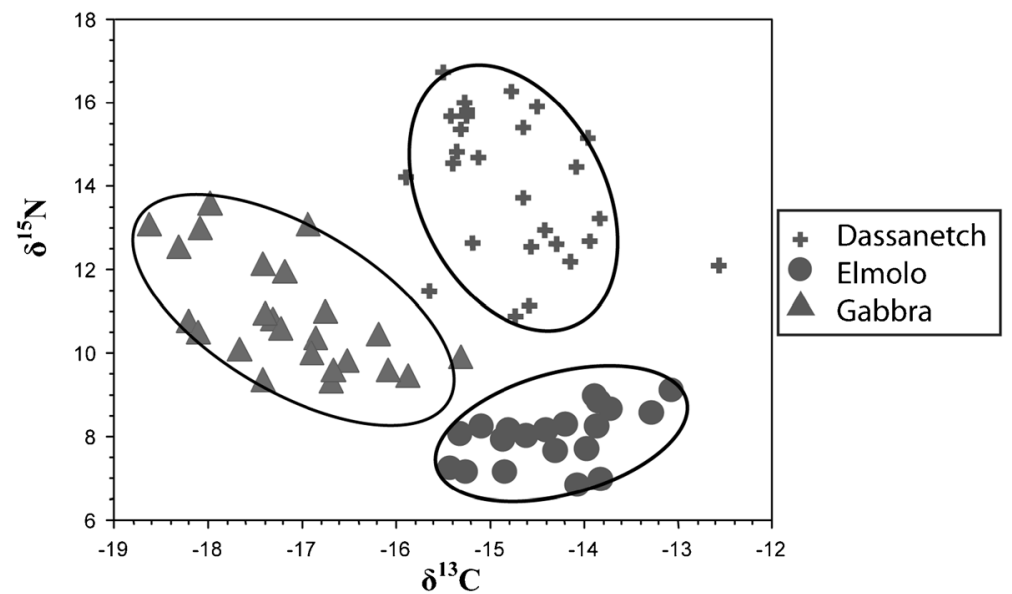

Fig. 8 Bivariate scattergram showing the $\delta^{13} \mathrm{C}$ and $\delta^{15} \mathrm{~N}$ values of Dassanetch, Elmolo, and Gabbra (Kiura 2005) 
LH subsistence diversification is also recorded among HP "pastoralists" when factors such as distance to markets, gender, family wealth, and local ecology are accounted (Little et al. 2001). The differences between how subsistence specialization takes form in the Turkana Basin between the LH and HP are more reflective of the synchronic nature of cultural anthropological data and diachronic nature of archaeological data than of true behavioral differences in people from the two periods.

Early ethnographic studies within the Turkana region suggest that clear patterning of subsistence according to ethnic affiliation was deeply ingrained in the cultural fabric of the region (Fig. 9; Gulliver 1951, 1955). Despite sharing a common language, settlement, and social structure, the Rendille and Ariaal pastoralists who inhabit contiguous territories in northern Kenya maintain distinct ethnic identities based on different modes of livestock production and ecological niche exploitation (Fratkin 1986). However, pastoralists like the Dassanetch and Turkana have traditionally been adept at absorbing immigrants into their communities and maintaining robust interethnic alliances so that they can access resource patches during ecologically challenging periods (de Vries et al. 2006; Sobania 1988, 2011). Schlee (1991) documents ritualized movements of nomadic pastoralists in the circum-Turkana region based on clan affiliations and scheduled circumcision rituals. An ethnoarchaeological site documented on the Mount Porr strand plain (GeJk18) was reported as the location of one such annual circumcision and marriage festival (Wright and Forman 2011). These movements reinforce social cohesion of the groups and maintain territorial boundaries based on competition for resources and ethnic affiliation.

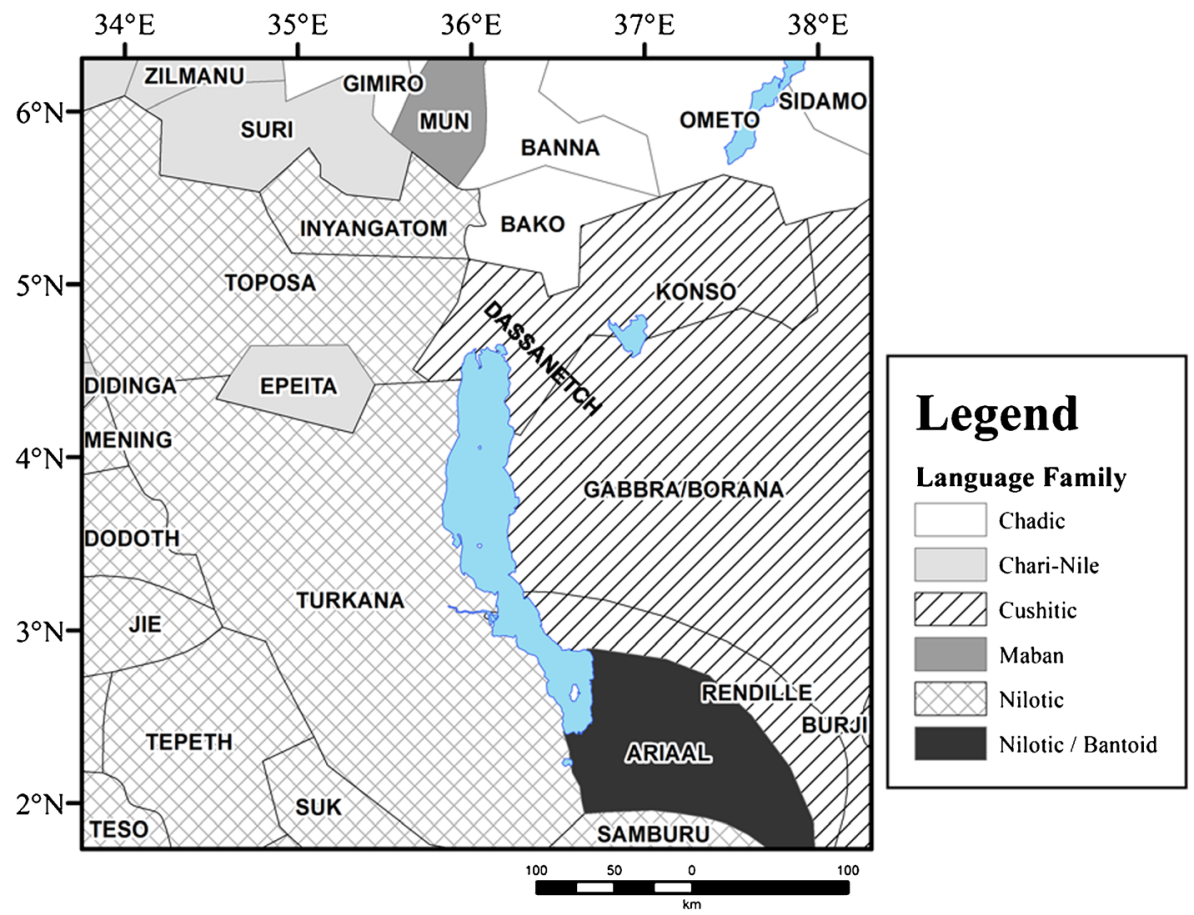

Fig. 9 Language groups of the Turkana Basin (Felix and Meur 2001) 
Over the last 50 years, the Turkana Basin has been pulled into the global economy and indigenous social networks have been refocused to control access to this new resource base. Oil has been discovered and is being drilled in select areas of the region. Prior to that, Lake Turkana was a focus of humanitarian efforts led by the United Nations, NGOs, Christian missionaries, and the Kenyan government, all of which had little understanding of the local economy (Fratkin 1991; McPeak and Barrett 2001; Middleton and O'Keefe 1997). With so many centers where nonlocal resources are infiltrating the region, there has been a substantial shift in the settlement ecology and nature of interactions between people living in the region. Presently, many pastoralists use the villages as child-rearing centers while males who are able to shepherd animals move from pasture to pasture, returning home occasionally to sell animals or resupply their families (de Vries et al. 2006; Fratkin 2001; Schlee 1991; Sun 2005). Conflicts over resource patches have also developed. In the past, interdependent social networks evolved over vast areas to mitigate risk associated with the changing climate. However, as the local economy is increasingly dependent on outside resources, there are fewer incentives to cooperate within the neighborhood and more incentives to fight a zerosum game for primacy in controlling access to those resources.

\section{Synthesis of Holocene Human-Climate Interactions in the Turkana Basin}

Understanding the past is critical for targeting resources into economic policies that make sense for the future. Economic investment in the developing world is increasingly focused on "sustainability," which requires understanding how past human societies adapted to climate change to maximize resilience and risk spreading in an increasingly precarious ecological landscape (Adger et al. 2013; Brooks et al. 2009; Dodman and Mitlin 2013). If not contextualized within the broader scope of Holocene climate change, temporary shifts in the distribution of monsoon rainfall may be erroneously perceived as a newfound agricultural development opportunity (Brooks et al. 2005). When monsoon patterns inevitably shift again, new nexuses of conflict arise (for an example from the western Sahara, see Keita 1998). The only way for policy makers to reduce cycles of conflict and unsustainable economic dependency is to facilitate indigenous approaches to mitigate risk and sustainably develop.

Studies of the Holocene evolution of the strand plain of Lake Turkana and the coinciding human responses are instructive for filling in the existing gaps of the culture history of Africa and present a case study for looking at human niche fulfillment in other closed lake basins. During the EH, the lake was part of a large sphere of lacustrineresource-dependent cultures that extended across the Sahara and Sahel during a pluvial period. Fishing with barbed bone points was the archaeological hallmark of these cultures, but given their vast distribution and scant evidence supporting an alternative hypothesis, ethnic and social links between the settlements were probably loose and dynamic. Subsistence was based on extracting local resources, and residential mobility was low. Therefore, the need for sustained and formalized exchange networks was also low.

In many parts of the world, the term "Neolithic" is used to describe a transformation in landscapes and cultural attributes from one that is comprised primarily of huntergatherers to one in which agricultural production is the major subsistence option (BarYosef 1998; Knitter 2008; Simmons 2007). Although the transition from a fully 
"untamed" to fully domesticated landscape is often incremental and nonlinear (Terrell et al. 2003), the adoption of the Neolithic complex in the Turkana Basin was exceptionally asymmetrical. Ceramics and microliths were introduced during the $\mathrm{EH}$ prior to formalized agriculture, while fishing and foraging were pursued long after domesticated animals appear (Barthelme 1985; Robbins 1984; Wright and Forman 2011).

During the EMH, more regularized exchange networks and expansions and/or migrations of culturally linked groups occurred against the backdrop of a progressively more arid climate across northern Africa. Old cultural exchange networks forged in the EH likely remained important aspects of new arid-adapted subsistence economies, which relied increasingly on pastoralism and less on shoreside foraging (Hoelzmann et al. 2001; Kuper and Kröpelin 2006). Likewise, as lake levels in Turkana transgress and regress tens of meters in subcentennial timescales, people adapted to new modes of subsistence and social interaction that were not as dependent on fish. Unfortunately, there is a paucity of direct evidence of human subsistence from this time period, but it is likely that during this period, as elsewhere in Africa, bone-point fishing was greatly reduced because large fish species became scarcer (Stewart 1989).

The LMH is a period characterized by diversification of subsistence options in the Lake Turkana Basin, especially in regards to the introduction of domesticated animals into the region under the backdrop of a consistently arid climate. This is a cultural incubation period in which transmission of ceremonial activities and raw materials is intense (and likely mirrors a wide range of other cultural facets), but localized. Despite the fact that there is ample evidence for increasing numbers of livestock being present in the Turkana region between 4,500 and 3,000 years BP, there is only scant evidence of the spread of herding into equatorial Africa until after 3,000 years BP (Bower 1991; Gifford-Gonzalez 1998, 2000; Lane 2004; Marshall and Hildebrand 2002; Wright 2011, 2013). Lower lake levels during the LMH reflect a generally reduced amount of annual precipitation brought by monsoons, which tethered people to predictable resource bases. During the final stage of lake regression at the end of the EMH and beginning of the $\mathrm{LMH}$, falling lake levels appear to have prompted the movement of livestock into the southern frontier of equatorial Africa (sensu Lane 2004).

From the beginning of the LH onwards, migrations and subsistence diversity characterize the Turkana region as lake levels slowly recovered from their LMH lows. The legacy of population movements is evident from the present-day distribution of two language families and four subfamilies spread across the basin (Ehret 2011, p. 117-119; Schlee 1985; Spear and Waller 1993). The archaeological record is not clear whether nomadic forms of pastoralism that took root across eastern Africa coexisted with riparian-based subsistence or people shifted between subsistence regimes as the environment predicated.

During the HP, historical documentation (lake gauges, travelers' accounts, aerial and satellite photos), stable isotope data, and the OSL geochronology show that there is tremendous variability in centennial-scale lake levels and human settlement patterns along the shoreline of Lake Turkana. During the early HP, settlement could be characterized as seasonally moving base-camp settlements. As stone-masonry missionary and government outposts are constructed within the region, the settlement patterns of HP people have also shifted adjacent to these permanent structures. Conflict over access to external resources is particularly acute during dry years when there are fewer local resources and intertribal cooperation networks have weakened since the early HP (McCabe 2004; Middleton and O’Keefe 1997). 
Although understanding the correspondence between changing lake levels and settlement patterns of the Lake Turkana region is important for augmenting the culturalhistorical framework of northern Kenya, the more significant application of the data comes from their applicability toward generally modeling human behavioral responses to profound shifts in ecology. The Turkana drainage basin and adjacent areas that fall within monsoon rainfall regions of Africa hosted specialized hunter-gatherers and early cattle herding cultures and has been a population migration corridor throughout the Holocene. The archaeological evidence from Lake Turkana shows that prehistoric people managed risk using alternating strategies of subsistence specialization and diversity, depending on what the ecological circumstances warranted. Further, investment in vast social networks created social capital certainly useful for survival during periods of climatic stress. As the inhabitants of the Turkana Basin become more dependent on outsiders to buffer their subsistence needs, there is less need to maintain regional cohesion and more incentive to fight for access to those scarce resources. A look at the archaeological evidence from the Turkana Basin shows that subsistence flexibility and cultural integration may prove to be a more enduring economic strategy in the face of climate change.

\section{Conclusion}

The shifting water level of Lake Turkana during the Holocene correlates to changes in the subsistence and settlement economies of the region and is instructive for understanding broader processes of human adaptation to environmental change. High lake levels during the EH facilitated the evolution of an aquatic-based subsistence strategy and localized, intensive foraging along the lake's margins. As the climate transitioned to more arid conditions, humans were forced to adapt to extreme oscillations in lake levels associated with highly variable precipitation. In northern Africa, steadily increasing aridity forced livestock keepers to seek new pastures, which likely followed trade and migration routes that were well-developed in the EH. Domesticated animals were probably not a critical part of the subsistence strategy of the Turkana Basin until the LMH when oscillating lake levels gave way to steadily decreasing lake levels and increasing salinity, making intensive fishing almost impossible for all inhabitants of the region. Pastoralism was well-adapted to the new, xeric landscape, and it is likely that people pursued mixed subsistence strategies until the HP, when more specialized forms of subsistence are recorded. The arrival of modern aid and governmental institutions has created a new source to meet subsistence needs, although the sustainability of such a model is unclear.

Lake Turkana is a cultural crossroads and microcosm for shifting modes of subsistence found in Africa during the Holocene. Although each region has followed its own evolutionary trajectory, the nuanced choices people made to survive Holocene environmental changes are reflected in the archaeological record of Lake Turkana and are useful for understanding how cultures elsewhere adapt to environmental stimuli. Subsistence changes are not always permanent or absolute as new challenges and opportunities may cause people to move between occupations as diverse as fishing and pastoralism.

Although Lake Turkana has yielded a rich archaeological and climatic record, more work is needed to fully understand the nuanced nature of diachronic technological changes associated with demographic and cultural movements during the Holocene. A comprehensive ceramic typology is absent and there are vast quantities of lithic 
materials archived in need of geochemical sourcing to trace out prehistoric interaction networks. Additional data are needed to constrain the amplitude of changes in lake levels during the Holocene. Lake level reconstructions need to employ modern GPS technology with tight controls on elevation and modern AMS radiocarbon techniques in order to more precisely and accurately constrain the position of the lake at different points in time. Such methods will also provide insight as to whether kinematic deformations of the lithosphere are responsible for creating conflicting lake level reconstructions.

As the rate of global climate change accelerates in the twenty-first century, understanding how people of the past adapted to prior instances of climate change is critical to calibrate the range of adaptive responses moving forward (Marchant and Lane 2014). The inhabitants of the Turkana Basin have proven resilient to extreme changes in their landscape by either engaging in generalized or specialized modes of subsistence as the circumstances warrant. Aid and development brought in from outside the region have become critical resources for people as populations have increased and other modes of subsistence have become increasingly strained. It is important to contextualize such assistance in the long view of the archaeological record. New technologies and subsistence strategies introduced from outside the Turkana region have a long precedent, especially in times of climatic change. However, prior introductions of exogenous innovations have been locally adapted to meet the needs of the local populations for subsequent centuries and millennia. It remains to be seen whether modern food assistance and capacity building are preparing the indigenous inhabitants of the region for future environmental changes.

Acknowledgments Research involved in undertaking archival research critical to the completion of this manuscript was funded by the National Research Foundation of South Korea (Grant \#2013S1A5A8021512) and the Research Settlement Fund for new faculty of Seoul National University to DKW. National Geographic Society, Committee for Research and Exploration grants \#8142-06 and 8456-08 awarded to DKW and SLF funded the primary research used to construct the lake level curve and archaeological research in the Mount Porr region. The research was conducted with permission from the Office of the President of the Republic of Kenya (permit MOHEST 13/001/30C 220) and in collaboration with the National Museums of Kenya Department of Earth Sciences. Angela Lamb provided data files for creating the isotopic graphics for Lake Tilo. Charles Nelson generously provided high-resolution images of Nderit Ware from his image library. One anonymous reviewer, Katherine Grillo, Stan Ambrose, Rod McIntosh, Jean Maley, and Adria LaViolette provided invaluable, constructive critiques and editorial guidance that improved this manuscript greatly. Katherine Grillo's comments even after formal acceptance of this paper were invaluable to correct a serious error in statement about pottery seriation. We would like to thank our past and present colleagues in the National Museums of Kenya for facilitating all of the archaeological research that has taken place in the Turkana region over the last century and we look forward to exploring new research frontiers together in the years to come.

Open Access This article is distributed under the terms of the Creative Commons Attribution 4.0 International License (http://creativecommons.org/licenses/by/4.0/), which permits unrestricted use, distribution, and reproduction in any medium, provided you give appropriate credit to the original author(s) and the source, provide a link to the Creative Commons license, and indicate if changes were made.

\section{References}

Adger, W. N., Barnett, J., Brown, K., Marshall, N., \& O’Brien, K. (2013). Cultural dimensions of climate change impacts and adaptation. Nature Climate Change, 3(2), 112-117.

Alexander, J. (1980). The spread and development of iron-using in Europe and Africa. In R. E. Leakey \& B. A. Ogot (Eds.), Proceedings of the 8th Panafrican Congress of Prehistory and Quaternary Studies (pp. 327-330). Nairobi: The International Louis Leakey Memorial Institute for African Prehistory. 
Ashley, G. M., Ndiema, E. K., Spencer, J. Q. G., Harris, J. W. K., \& Kiura, P. W. (2011). Paleoenvironmental context of archaeological sites, implications for subsistence strategies under Holocene climate change, northern Kenya. Geoarchaeology, 26(6), 809-837.

Avery, S. (2010). Hydrological impacts of Ethiopia's Omo Basin on Kenya's Lake Turkana water levels and fisheries. Final report. Tunis: African Development Bank Group.

Bard, E., Hamelin, B., \& Fairbanks, R. G. (1990). U-Th ages obtained by mass spectrometry in corals from Barbados: Sea level during the past 130,000 years. Nature, 346, 456-458.

Bard, E., Rostek, F., \& Sonzogni, C. (1997). Interhemispheric synchrony of the last deglaciation inferred from alkenone palaeothermometry. Nature, 385, 707-710.

Barham, L., \& Mitchell, P. M. (2008). The first Africans: African archaeology from the earliest toolmakers to most recent foragers. Cambridge: University of Cambridge Press.

Barich, B. E. (2002). Cultural responses to climatic changes in North Africa: Beginning and spread of pastoralism in the Sahara. In F. A. Hassan (Ed.), Droughts, food and culture: Ecological change and food security in Africa's later prehistory (pp. 209-223). New York: Kluwer Academic/Plenum.

Barker, P. A., Street-Perrott, F. A., Leng, M. J., Greenwood, P. B., Swain, D. L., Perrott, R. A., Telford, R. J., \& Ficken, K. J. (2001). A 14,000-year oxygen isotope record from diatom silica in two alpine lakes on Mt. Kenya. Science, 292(5525), 2307-2310.

Barker, P. A., Telford, R. J., Gasse, F., \& Thevenon, F. (2002). Late Pleistocene and Holocene palaeohydrology of Lake Rukwa, Tanzania, inferred from diatom analysis. Palaeogeography, Palaeoclimatology, Palaeoecology, 187(3-4), 295-305.

Barthelme, J. W. (1985). Fisher-hunters and Neolithic pastoralists in East Turkana, Kenya (Vol. 254). Oxford: BAR International.

Bar-Yosef, O. (1998). On the nature of transitions: The Middle to Upper Palaeolithic and the Neolithic Revolution. Cambridge Archaeological Journal, 8(2), 141-163.

Batai, K., Babrowski, K. B., Arroyo, J. P., Kusimba, C. M., \& Williams, S. R. (2013). Mitochondrial DNA diversity in two ethnic groups in southeastern Kenya: Perspectives from the northeastern periphery of the Bantu expansion. American Journal of Physical Anthropology, 150(3), 482-491.

Bergner, A. G. N., \& Trauth, M. H. (2004). Comparison of the hydrological and hydrochemical evolution of Lake Naivasha (Kenya) during three highstands between 175 and 60 kyr BP. Palaeogeography, Palaeoclimatology, Palaeoecology, 215(1-2), 17-36.

Berke, M. A., Johnson, T. C., Werne, J. P., Schouten, S., \& Damsté, J. S. S. (2012a). A mid-Holocene thermal maximum at the end of the African Humid Period. Earth and Planetary Science Letters, 351-352, 95104.

Berke, M. A., Johnson, T. C., Werne, J. P., Grice, K., Schouten, S., \& Sinninghe Damsté, J. S. (2012b). Molecular records of climate variability and vegetation response since the Late Pleistocene in the Lake Victoria basin, East Africa. Quaternary Science Reviews, 55, 59-74.

Beuning, K. R. M., Talbot, M. R., \& Kelts, K. (1997). A revised 30,000-year paleoclimatic and paleohydrologic history of Lake Albert, East Africa. Palaeogeography, Palaeoclimatology, Palaeoecology, 136, 259-279.

Beyin, A. (2011). Recent archaeological survey and excavation around the greater Kalokol area, west side of Lake Turkana: Preliminary findings. Nyame Akuma, 75, 40-50.

Bloszies, C., Forman, S. L., \& Wright, D. K. (in press). Water level history for Lake Turkana, Kenya in the past 15,000 years and a variable transition from the African Humid Period to Holocene aridity. Global and Planetary Change.

Bloszies, C., \& Forman, S. L. (2015). Potential relation between equatorial sea surface temperatures and historic water level variability for Lake Turkana, Kenya. Journal of Hydrology, 520, 489-501.

Boattini, A., Castrì, L., Sarno, S., Useli, A., Cioffi, M., Sazzini, M., Garagnani, P., De Fanti, S., Pettener, D., \& Luiselli, D. (2013). mtDNA variation in East Africa unravels the history of Afro-Asiatic groups. American Journal of Physical Anthropology, 150(3), 375-385.

Bower, J. R. F. (1991). The Pastoral Neolithic of East Africa. Journal of World Prehistory, 5, 49-82.

Bower, J. R. F. (1996). Early food production in Africa. Evolutionary Anthropology, 4, 130-139.

Bower, J. R. F., \& Nelson, C. M. (1978). Early pottery and pastoral cultures of the Central Rift Valley, Kenya. Man, 13, 554-566.

Bower, J. R. F., Nelson, C. M., Waibel, A. F., \& Wandibba, S. (1977). The University of Massachusetts' Later Stone Age/Pastoral 'Neolithic' comparative study in Central Kenya: An overview. Azania, 12, 119-146.

Braconnot, P., Joussaume, S., de Noblet, N., \& Ramstein, G. (2000). Mid-Holocene and last glacial maximum African monsoon changes as simulated within the paleoclimate modelling intercomparison project. Global and Planetary Change, 26(1-3), 51-66. 
Brandt, S. A., \& Carder, N. (1987). Pastoral rock art in the Horn of Africa: Making sense of udder chaos. World Archaeology, 19(2), 194-213.

Brooks, N., Chiapello, I., Lernia, S. D., Drake, N., Legrand, M., Moulin, C., \& Prospero, J. (2005). The climate-environment-society nexus in the Sahara from prehistoric times to the present day. The Journal of North African Studies, 10(3-4), 253-292.

Brooks, N., Grist, N., \& Brown, K. (2009). Development futures in the context of climate change: Challenging the present and learning from the past. Development Policy Review, 27(6), 741-765.

Brown, F. H. (1975). Barbed bone points from the Lower Omo Valley, Ethiopia. Azania, 10, 144-148.

Brown, F. H., \& Fuller, C. R. (2008). Stratigraphy and tephra of the Kibish Formation, southwestern Ethiopia. Journal of Human Evolution, 55(3), 366-403.

Butzer, K. W. (1971). Recent history of an Ethiopian delta. Chicago: University of Chicago Department of Geography Research Paper.

Butzer, K. W. (1980). The Holocene lake plain of north Rudolf, East Africa. Physical Geography, 1, 42-58.

Butzer, K. W., Isaac, G. L., Richardson, J., \& Washburn-Kamau, C. (1972). Radiocarbon dating of East African lake levels. Science, 175, 1069-1076.

Castañeda, I. S., Mulitza, S., Schefuß, E., Lopes dos Santos, R. A., Sinninghe Damsté, J. S., \& Schouten, S. (2009). Wet phases in the Sahara/Sahel region and human migration patterns in North Africa. Proceedings of the National Academy of Sciences, 106(48), 20159-20163.

Castrì, L., Garagnani, P., Useli, A., Pettener, D., \& Luiselli, D. (2008). Kenyan crossroads: Migration and gene flow in six ethnic groups from eastern Africa. Journal of Archaeological Science, 86, 189-192.

Cerling, T. E. (1979). Paleochemistry of Plio-Pleistocene Lake Turkana, Kenya. Palaeogeography, Palaeoclimatology, Palaeoecology, 27, 247-285.

Černý, V., Fernandes, V., Costa, M., Hájek, M., Mulligan, C., \& Pereira, L. (2009). Migration of Chadic speaking pastoralists within Africa based on population structure of Chad basin and phylogeography of mitochondrial L3f haplogroup. BMC Evolutionary Biology, 9(1), 63.

Conway, D. (2000). The climate and hydrology of the Upper Blue Nile River. Geographical Journal, 166(1), 49-62.

Conway, D., Mould, C., \& Bewket, W. (2004). Over one century of rainfall and temperature observations in Addis Ababa, Ethiopia. International Journal of Climatology, 24(1), 77-91.

Costa, K., Russell, J., Konecky, B., \& Lamb, H. (2014). Isotopic reconstruction of the African Humid Period and Congo Air Boundary migration at Lake Tana, Ethiopia. Quaternary Science Reviews, 83, 58-67.

de Vries, D., Leslie, P. W., \& McCabe, J. T. (2006). Livestock acquisitions dynamics in nomadic pastoralist herd demography: A case study among Ngisonyoka herders of South Turkana, Kenya. Human Ecology, $34(1), 1-25$.

Dodman, D., \& Mitlin, D. (2013). Challenges for community-based adaptation: Discovering the potential for transformation. Journal of International Development, 25(5), 640-659.

Dunkelman, T. J., Karson, J. A., \& Rosendahl, B. R. (1988). Structural style of the Turkana Rift, Kenya. Geology, 16(3), 258-261.

Ehret, C. (1974). Ethiopians and East Africans: The problem of contacts. Nairobi: East African Publishing House.

Ehret, C. (1979). On the antiquity of agriculture in Ethiopia. The Journal of African History, 20, 161-177.

Ehret, C. (1993). Nilo-Saharans and the Sahara-Sudanese Neolithic. In T. Shaw, P. Sinclair, B. Andah, \& A. Okpoko (Eds.), The archaeology of Africa: Food, metals and towns (vol. 104-125). London: Routledge.

Ehret, C. (1998). An African classical age: Eastern and southern Africa in world history, 1000 BC to AD 400. Charlottesville: University Press of Virginia.

Ehret, C. (2011). History and the testimony of language. Berkeley: University of California Press.

Felix, M., \& Meur, C. (2001). People's atlas of Africa, http://worldmap.harvard.edu/africamap/. Brussels: Congo Basin Art History Research Center.

Ferguson, A. J. D., \& Harbott, B. J. (1982). Geographical, physical and chemical aspects of Lake Turkana. In A. J. Hopson (Ed.), Lake Turkana: A report on the findings of the Lake Turkana project 1972-1975 (pp. 1-107). London: Overseas Development Administration. Institute of Aquaculture. University of Stirling.

Fernández, V. M., del la Torre, L., Luque, L., González-Ruibal, A., \& López-Sáez, J. A. (2007). A Late Stone Age sequence from West Ethiopia: The sites of K'aaba and Bel K'urk'uma (Assosa, Benishangul-Gumuz Regional State). Journal of African Archaeology, 5(1), 91-126.

Foerster, V., Junginger, A., Langkamp, O., Gebru, T., Asrat, A., Umer, M., Lamb, H., Wennrich, V., Rethemeyer, J., Nowaczyk, N., Trauth, M. H., \& Schaebitz, F. (2012). Climatic change recorded in the sediments of the Chew Bahir basin, southern Ethiopia, during the last 45,000 years. Quaternary International, 274, 25-37. 
Forman, S. L., Wright, D. K., \& Bloszies, C. (2014). Variations in water level for Lake Turkana in the past 8500 years near Mt. Porr, Kenya and the transition from the African Humid Period to Holocene aridity. Quaternary Science Reviews, 97, 84-101.

Fratkin, E. (1986). Stability and resilience in East African pastoralism: The Rendille and the Ariaal of northern Kenya. Human Ecology, 14(3), 269-286.

Fratkin, E. (1991). Surviving drought and development: Ariaal pastoralists of Northern Kenya. Boulder: Westview Press.

Fratkin, E. (2001). East African pastoralism in transition: Maasai, Boran, and Rendille cases. African Studies Review, 44(3), 1-25.

Garcin, Y., Junginger, A., Melnick, D., Olago, D. O., Strecker, M. R., \& Trauth, M. H. (2009). Late Pleistocene-Holocene rise and collapse of Lake Suguta, northern Kenya Rift. Quaternary Science Reviews, 28(9-10), 911-925.

Garcin, Y., Melnick, D., Strecker, M. R., Olago, D., \& Tiercelin, J.-J. (2012). East African mid-Holocene wetdry transition recorded in palaeo-shorelines of Lake Turkana, northern Kenya Rift. Earth and Planetary Science Letters, 331-332, 322-334.

Gasse, F. (2000). Hydrological changes in the African tropics since the last glacial maximum. Quaternary Science Reviews, 19(1-5), 189-211.

Gasse, F., \& Van Campo, E. (1994). Abrupt post-glacial climate events in West Asia and North Africa monsoon domains. Earth and Planetary Science Letters, 126(4), 435-456.

Gasse, F., Chalié, F., Vincens, A., Williams, M. A. J., \& Williamson, D. (2008). Climatic patterns in equatorial and southern Africa from 30,000 to 10,000 years ago reconstructed from terrestrial and near-shore proxy data. Quaternary Science Reviews, 27(25-26), 2316-2340.

Gifford-Gonzalez, D. (1998). Early pastoralists in East Africa: Ecological and social dimensions. Journal of Anthropological Archaeology, 17, 166-200.

Gifford-Gonzalez, D. (2000). Animal disease challenges to the emergence of pastoralism in sub-Saharan Africa. African Archaeological Review, 17(3), 95-139.

Gifford-Gonzalez, D. (2003). The fauna from Ele Bor: Evidence for the persistence of foragers into the Later Holocene of arid North Kenya. African Archaeological Review, 20(2), 81-119.

Gillespie, R., Street-Perrott, F. A., \& Switsur, R. (1983). Post-glacial arid episodes in Ethiopia have implications for climate prediction. Nature, 306, 680-682.

Golubtsov, A. S., \& Habteselassie, R. (2010). Fish faunas of the Chamo-Abaya and Chew Bahir basins in southern portion of the Ethiopian Rift Valley: Origin and prospects for survival. Aquatic Ecosystem Health \& Management, 13(1), 47-55.

Grillo, K. M., \& Hildebrand, E. A. (2013). The context of early megalithic architecture in eastern Africa: The Turkana Basin c. 5000-4000 BP. Azania: Archaeological Research in Africa, 48(2), 193-217.

Grove, A. T., Street, F. A., \& Goudie, A. S. (1975). Former lake levels and climatic change in the Rift Valley of southern Ethiopia. The Geographical Journal, 141(2), 177-194.

Gulliver, P. H. (1951). A preliminary survey of the Turkana (Vol. 26). Cape Town: Communication from the School of African Studies, University of Cape Town.

Gulliver, P. H. (1955). The family herds. London: Routledge.

Haaland, R. (1992). Fish, pots and grain: Early and Mid-Holocene adaptations in the Central Sudan. African Archaeological Review, 10, 43-64.

Haaland, R. (1993). Aqualithic sites of the Middle Nile. Azania: Archaeological Research in Africa, 28(1), 47-86.

Halfman, J. D., \& Johnson, T. C. (1988). High-resolution of cyclic climate change during the past $4 \mathrm{ka}$ from Lake Turkana, Kenya. Geology, 16, 496-500.

Halfman, J. D., Jacobson, D. F., Cannela, C. M., Haberyan, K. A., \& Finney, B. P. (1992). Fossil diatoms and the mid to late Holocene paleolimnology of Lake Turkana, Kenya: A reconnaissance study. Journal of Paleolimnology, 7(1), 23-35.

Hamilton, A. C. (1982). Environmental history of East Africa. London: Academic.

Hildebrand, E., \& Grillo, K. (2012). Early herders and monumental sites in eastern Africa: Dating and interpretation. Antiquity, 86(332), 338-352.

Hildebrand, E., Shea, J., \& Grillo, K. (2011). Four middle Holocene pillar sites in West Turkana, Kenya. Journal of Field Archaeology, 36(3), 181-200.

Hildebrand, E., Grillo, K., \& Janzen, A. (2014). Construction of megalithic pillar sites in the Middle Holocene of NW Kenya: Social change on an economic frontier. Paper presented at the Society for American Archaeologists' 79th Annual Meeting, Austin, Texas 
Hoelzmann, P., Keding, B., Berke, H., Kropelin, S., \& Kruse, H. J. (2001). Environmental change and archaeology: Lake evolution and human occupation in the eastern Sahara during the Holocene. Palaeogeography, Palaeoclimatology, Palaeoecology, 169(3-4), 193-217.

Johnson, T. C., \& Malala, J. O. (2009). Lake Turkana and its link to the Nile. In H. J. Dumont (Ed.), The Nile: Origin, environments, limnology, and human use (pp. 287-304). Dordrecht: Springer.

Johnson, T. C., Halfman, J. D., Rosendahl, B. R., \& Lister, G. S. (1987). Climatic and tectonic effects on sedimentation in a rift-valley lake-Evidence from high-resolution seismic profiles, Lake Turkana, Kenya. Geological Society of America Bulletin, 98(4), 439-447.

Junginger, A., Roller, S., Olaka, L. A., \& Trauth, M. H. (2014). The effects of solar irradiation changes on the migration of the Congo Air boundary and water levels of paleo-Lake Suguta, Northern Kenya Rift, during the African Humid Period (15-5 ka BP). Palaeogeography, Palaeoclimatology, Palaeoecology, 396, 116.

Jury, M. (2010). Ethiopian decadal climate variability. Theoretical and Applied Climatology, 101(1), 29-40.

Källqvist, T., Lien, L., \& Liti, D. (1988). Lake Turkana: Limonological study 1985-1988. Blindern: Norwegian Institute for Water Research.

Keita, K. (1998). Conflict and conflict resolution in the Sahel: The Tuareg insurgency in Mali. Small Wars \& Insurgencies, 9(3), 102-128.

Kiura, P. W. (2005). An ethnoarchaeology and stable isotope study on the diets of three modern groups of people in northern Kenya. Ph.D. dissertation, Rutgers University.

Kizza, M., Rodhe, A., Xu, C.-Y., Ntale, H., \& Halldin, S. (2009). Temporal rainfall variability in the Lake Victoria Basin in East Africa during the twentieth century. Theoretical and Applied Climatology, 98(1-2), 119-135.

Knitter, D. (2008). Holocene landscape development: How (pre-)historic man changed our environment. Noderstedt: GRIN Verlag.

Krom, M. D., Stanley, J. D., Cliff, R. A., \& Woodward, J. C. (2002). Nile River sediment fluctuations over the past $7000 \mathrm{yr}$ and their key role in sapropel development. Geology, 30(1), 71-74.

Kröpelin, S., Verschuren, D., Lézine, A.-M., Eggermont, H., Cocquyt, C., Francus, P., Cazet, J.-P., Fagot, M., Russell, J. M., Darius, F., Conley, D. J., Schuster, M., von Suchodoletz, H., \& Engstrom, D. R. (2008). Climate-driven ecosystem succession in the Sahara: The past 6000 years. Science, 320(5877), 765-768.

Kuper, R., \& Kröpelin, S. (2006). Climate-controlled Holocene occupation in the Sahara: Motor of Africa's evolution. Science, 313(5788), 803-807.

Kuper, R., \& Riemer, H. (2013). Herders before Pastoralism Prehistoric Prelude in the Eastern Sahara. In M. Bollig, M. Schnegg, \& H.-P. Wotzka (Eds.), Pastoralism in Afirca: Past, Present, and Future (pp. 31-65). New York: Berghahn Books.

Lamb, A. L., Leng, M. J., Lamb, H. F., \& Mohammed, M. U. (2000). A 9000-year oxygen and carbon isotope record of hydrological change in a small Ethiopian crater lake. The Holocene, 10(2), 167-177.

Lamb, H. F., Leng, M. J., Telford, R. J., Ayenew, T., \& Umer, M. (2007). Oxygen and carbon isotope composition of authigenic carbonate from an Ethiopian lake: A climate record of the last 2000 years. The Holocene, 17(4), 517-526.

Lane, P. (2004). The 'moving frontier' and the transition to food production in Kenya. Azania, 39, $243-264$.

Le Gall, B., Vétel, W., \& Morley, C. K. (2005). Inversion tectonics during continental rifting: The Turkana Cenozoic rifted zone, northern Kenya. Tectonics, 24(2), TC2002.

Lesur, J. (2007). Chasse et élevage dans la Corne de l'Afrique entre le Néolithique et les temps historiques (Cambridge Monographs in African Archaeology). Oxford: BAR International Series 1602.

Lesur, J., Hildebrand, E. A., Abawa, G., \& Gutherz, X. (2014). The advent of herding in the Horn of Africa: New data from Ethiopia, Djibouti and Somaliland. Quaternary International, 343, 148-158.

Levin, N. E., Zipser, E. J., \& Cerling, T. E. (2009). Isotopic composition of waters from Ethiopia and Kenya: Insights into moisture sources for eastern Africa. Journal of Geophysical Research, [Atmospheres], 114(D23), D23306.

Linseele, V., Van Neer, W., Thys, S., Phillipps, R., Cappers, R., Wendrich, W., et al. (2014). New archaeozoological data from the Fayum "Neolithic" with a critical assessment of the evidence for early Stock Keeping in Egypt. PLoS ONE, 9(10), e108517.

Little, P. D., Smith, K., Cellarius, B. A., Coppock, D. L., \& Barrett, C. (2001). Avoiding disaster: Diversification and risk management among East African herders. Development and Change, 32(3), 401-433.

Liu, Z., Otto-Bliesner, B., Kutzbach, J., Li, L., \& Shields, C. (2003). Coupled climate simulation of the evolution of global monsoons in the Holocene. Journal of Climate, 16(15), 2472-2490.

Lynch, B. M., \& Robbins, L. H. (1978). Namoratunga: The first archeoastronomical evidence in sub-Saharan Africa. Science, 200(4343), 766-768. 
Lynch, B. M., \& Robbins, L. H. (1979). Cushitic and Nilotic prehistory: New archaeological evidence from north-west Kenya. Journal of African History, 20(3), 319-328.

Mace, R. (1993). Transitions between cultivation and pastoralism in sub-Saharan Africa. Current Anthropology, 34, 363-382.

Madella, M., García-Granero, J. J., Out, W. A., Ryan, P., \& Usai, D. (2014). Microbotanical evidence of domestic cereals in Africa 7000 years ago. PLoS ONE, 9(10), e110177.

Marchant, R., \& Lane, P. (2014). Past perspectives for the future: Foundations for sustainable development in East Africa. Journal of Archaeological Science, 51, 12-21.

Marshall, F. (1990). Origins of specialized pastoral production in East Africa. American Anthropologist, 92(4), 873-894.

Marshall, F. (2000). The origins and spread of domestic animals in East Africa. In K. C. MacDonald \& R. M. Blench (Eds.), The origins and development of African livestock: Archaeology, genetics, linguistics and ethnography (pp. 191-221). London: UCL Press.

Marshall, F., \& Hildebrand, E. (2002). Cattle before crops: The beginnings of food production in Africa. Journal of World Prehistory, 16(2), 99-143.

Marshall, F., Stewart, K., \& Barthelme, J. W. (1984). Early domestic stock at Dongodien in northern Kenya. Azania, 19, 120-129.

Marshall, M. H., Lamb, H. F., Davies, S. J., Leng, M. J., Kubsa, Z., \& Umer, M. (2009). Climatic change in northern Ethiopia during the past 17,000 years: A diatom and stable isotope record from Lake Ashenge. Palaeogeography, Palaeoclimatology, Palaeoecology, 279(1-2), 114-127.

Marshall, M. H., Lamb, H. F., Huws, D., Davies, S. J., Bates, R., Bloemendal, J., Boyle, J., Leng, M. J., Umer, M., \& Bryant, C. (2011). Late Pleistocene and Holocene drought events at Lake Tana, the source of the Blue Nile. Global and Planetary Change, 78(3-4), 147-161.

Mayewski, P. A., Rohling, E. E., Curt Stager, J., KarlĖn, W., Maasch, K. A., David Meeker, L., Meyerson, E. A., Gasse, F., van Kreveld, S., \& Holmgren, K. (2004). Holocene climate variability. Quaternary Research, 62(3), 243-255.

McCabe, J. T. (2004). Cattle bring us to our enemies: Turkana ecology, politics, and raiding in a disequilibrium system (Vol. 2). Ann Arbor: University of Michigan Press.

McPeak, J. G., \& Barrett, C. B. (2001). Differential risk exposure and stochastic poverty traps among East African pastoralists. American Journal of Agricultural Economics, 83(3), 674-679.

Melnick, D., Garcin, Y., Quinteros, J., Strecker, M. R., Olago, D., \& Tiercelin, J.-J. (2012). Steady rifting in northern Kenya inferred from deformed Holocene lake shorelines of the Suguta and Turkana basins. Earth and Planetary Science Letters, 331-332, 335-346.

Ménard, C., Bon, F., Dessie, A., Bruxelles, L., Douze, K., Fauvelle, F.-X., Khalidi, L., Lesur, J., \& Mensan, R. (2014). Late Stone Age variability in the Main Ethiopian Rift: New data from the Bulbula River, ZiwayShala basin. Quaternary International, 343, 53-68.

Middleton, N., \& O'Keefe, P. (1997). Disaster and development: The politics of humanitarian aid. London: Pluto Press.

Mohammed, M. U., Bonnefille, R., \& Johnson, T. C. (1995). Pollen and isotopic records in Late Holocene sediments from Lake Turkana, Kenya. Palaeogeography, Palaeoclimatology, Palaeoecology, 119, 371383.

Mohammed-Ali, A. S., \& Khabir, A.-R. M. (2003). The wavy line and the dotted wavy line pottery in the prehistory of the Central Nile and the Sahara-Sahel Belt. African Archaeological Review, 20(1), $25-58$.

Morrissey, A., \& Scholz, C. A. (2014). Paleohydrology of Lake Turkana and its influence on the Nile River system. Palaeogeography, Palaeoclimatology, Palaeoecology, 403, 88-100.

Mutundu, K. K. (2010). An ethnoarchaeological framework for the identification and distinction of Late Holocene archaeological sites in East Africa. Azania: Archaeological Research in Africa, 45(1), 6-23.

Nash, B. P., Merrick, H. V., \& Brown, F. H. (2011). Obsidian types from Holocene sites around Lake Turkana, and other localities in northern Kenya. Journal of Archaeological Science, 38, 1371-1376.

Ndiema, E. K., Dillian, C. D., Braun, D. R., Harris, J. W. K., \& Kiura, P. W. (2011). Transport and subsistence patterns at the transition to pastoralism, Koobi Fora, Kenya. Archaeometry, 53(6), 1085-1098.

Nelson, C. M. (1995). Work of the Koobi Fora Field School at the Jarigole pillar site. Kenya Past and Present, 27, 49-63.

Nicholson, S. E. (1996). A review of climate dynamics and climate variability in eastern Africa. In T. C. Johnson \& E. O. Odada (Eds.), The limnology, climatology and paleoclimatology of the East African lakes (pp. 25-56). Amsterdam: Gordon and Breach Publishers.

Nyamweru, C. (1989). New evidence for the former extent of the Nile drainage system. The Geographical Journal, 155(2), 179-188. 
Olago, D. O., Street-Perrott, F. A., Perrott, R. A., Ivanovich, M., Harkness, D., \& Odada, E. O. (2000). Longterm temporal characteristics of palaeomonsoon dynamics in equatorial Africa. Global and Planetary Change, 26(1-3), 159-171.

Olaka, L., Odada, E., Trauth, M., \& Olago, D. (2010). The sensitivity of East African rift lakes to climate fluctuations. Journal of Paleolimnology, 44(2), 629-644.

Overpeck, J., Anderson, D., Trumbore, S., \& Prell, W. (1996). The southwest Indian monsoon over the last 18, 000 years. Climate Dynamics, 12(3), 213-225.

Owen, R. B., Barthelme, J. W., Renaut, R. W., \& Vincens, A. (1982). Palaeolimnology and archaeology of Holocene deposits north-east of Lake Turkana, Kenya. Nature, 298, 523-529.

Parkingham, T. (1991). The scramble for Africa. London: Abacus.

Phillipson, D. W. (1977). Lowasera. Azania, 7, 1-32.

Phillipson, D. W. (1984). Aspects of early food production in northern Kenya. In L. Krzyzaniak \& M. Kobusiewicz (Eds.), Origin and early development of food-producing cultures in North-Eastern Africa (pp. 489-495). Poznan: Polish Academy of Sciences.

Robbins, L. H. (1972). Archeology in the Turkana District, Kenya. Science, 176(4033), 359-366.

Robbins, L. H. (1974). The Lothagam site. East Lansing: Anthropological Series, Vol 1, No. 2. Michigan State University Museum.

Robbins, L. H. (1980). Lopoy: A Late Stone Age fishing and pastoralist settlement in the Lake Turkana Basin, Kenya. East Lansing: Anthropological Series, Vol 3, No. 1. Michigan State University Museum.

Robbins, L. H. (1984). Late prehistoric and aquatic adaptations west of Lake Turkana, Kenya. In J. D. Clark \& S. A. Brandt (Eds.), Hunters to farmers: Causes and consequences of food production in Africa (pp. 206211). Berkeley: University of California Press.

Robbins, L. H. (2006). Lake Turkana archaeology: The Holocene. Ethnohistory, 53(1), 71-93.

Robbins, L. H., \& Lynch, M. (1978). New evidence on the use of microliths from the Lake Turkana Basin, East Africa. Current Anthropology, 19(3), 619-620.

Robertshaw, P. T. (1995). The last 200,000 years in Eastern Africa. Journal of Archaeological Research, 3(1), 55-86.

Schefuß, E., Kuhlmann, H., Mollenhauer, G., Prange, M., \& Pätzold, J. (2011). Forcing of wet phases in southeast Africa over the past 17,000 years. Nature, 480, 509-512.

Schlee, G. (1985). Interethnic clan identities among Cushitic-speaking pastoralists. Africa, 55(1), 17-38.

Schlee, G. (1991). Traditional pastoralists - Land use strategies. In H. J. Schwartz, S. Shaabani, \& D. Walther (Eds.), Range management handbook of Kenya, volume II (1) (pp. 130-164). Nairobi: Ministry of Livestock Development.

Simmons, A. H. (2007). The Neolithic Revolution in the Near East: Transforming the human landscape. Tucson: University of Arizona Press.

Sobania, N. (1988). Fishermen herders: Subsistence, survival and cultural change in Northern Kenya. The Journal of African History, 29(Special Issue 1), 56.

Sobania, N. (2011). The formation of ethnic identity in South Omo: The Dassenech. Journal of Eastern African Studies, 5(1), 195-210.

Soper, R. (1982). Archaeo-astronomical Cushites: Some comments. Azania: Archaeological Research in Africa, 17(1), 145-162.

Spear, T., \& Waller, R. (Eds.). (1993). Being Maasai: Ethnicity and identity in East Africa. London: James Currey.

Stager, J. C., \& Mayewski, P. (1997). Abrupt Early to Mid-Holocene climatic transition registered at the Equator and the poles. Science, 276, 1834-1836.

Stewart, K. M. (1989). Fishing sites of North and East Africa in the Late Pleistocene and Holocene: Environmental change and adaptation (Cambridge Monographs in African Archaeology 34). Oxford: BAR International Series 521.

Sun, X. (2005). Dynamics of continuity and change in pastoral subsistence among the Rendille in northern Kenya: With special reference to livestock management and responses to socio-economic change. African Studies Monographs, 31(1), 1-94.

Sutton, J. E. G. (1974). The aquatic civilization of Middle Africa. Journal of African History, 15, $507-546$.

Sutton, J. E. G. (1977). The African aqualithic. Antiquity, 51, 25-34.

Terrell, J. E., Hart, J. P., Barut, S., Cellinese, N., Curet, A., Denham, T., Kusimba, C. M., Latinis, K., Oka, R., Palka, J., Pohl, M. E. D., Pope, K. O., Williams, P. R., Haines, H., \& Staller, J. E. (2003). Domesticated landscapes: The subsistence ecology of plant and animal domestication. Journal of Archaeological Method and Theory, 10(4), 323-368. 
Thevenon, F., Williamson, D., \& Taieb, M. (2002). A 22 kyr BP sedimentological record of Lake Rukwa (8 degrees S, SW Tanzania): Environmental, chronostratigraphic and climatic implications. Palaeogeography, Palaeoclimatology, Palaeoecology, 187(3-4), 285-294.

Tiercelin, J. J., Mondeguer, A., Gasse, F., Hillairemarcel, C., Hoffert, M., Larque, P., Ledee, V., Marestang, P., Ravenne, C., Raynaud, J.-F., Thouveny, N., Vincens, A., \& Williamson, D. (1988). 25,000 years of hydrological and sedimentary history of Lake Tanganyika, East-African Rift. Comptes Rendus de l'Académie des Sciences Serie Ii, 307(11), 1375-1382.

Tierney, J. E., \& deMenocal, P. B. (2013). Abrupt shifts in Horn of Africa hydroclimate since the last glacial maximum. Science, 342(6160), 843-846.

Tierney, J. E., Russell, J. M., \& Huang, Y. (2010). A molecular perspective on Late Quaternary climate and vegetation change in the Lake Tanganyika basin, East Africa. Quaternary Science Reviews, 29(5-6), 787800 .

Tierney, J. E., Lewis, S. C., Cook, B. I., LeGrande, A. N., \& Schmidt, G. A. (2011). Model, proxy and isotopic perspectives on the East African Humid Period. Earth and Planetary Science Letters, 307(1-2), 103-112.

Tierney, J. E., Smerdon, J. E., Anchukaitis, K. J., \& Seager, R. (2013). Multidecadal variability in East African hydroclimate controlled by the Indian Ocean. Nature, 493(7432), 389-392.

Umer, M., Legesse, D., Gasse, F., Bonnefille, R., Lamb, H. F., Leng, M. J., \& Lamb, A. L. (2004). Late Quaternary climate changes in the Horn of Africa. In R. W. Battarbee, F. Gasse, \& C. E. Stickley (Eds.), Past climate variability through Europe and Africa (Vol. 6, pp. 159-180). Dordrecht: Springer.

Ummenhofer, C. C., Sen Gupta, A., England, M. H., \& Reason, C. J. C. (2009). Contributions of Indian Ocean sea surface temperatures to enhanced East African rainfall. Journal of Climate, 22(4), 993-1013.

Velpuri, N. M., Senay, G. B., \& Asante, K. O. (2012). Using multi-source satellite data for lake level modelling in ungauged basins: A case study for Lake Turkana, East Africa. Hydrology and Earth System Sciences Discussions, 8(4851-4890).

Vétel, W., Le Gall, B., \& Johnson, T. C. (2004). Recent tectonics in the Turkana Rift (North Kenya): An integrated approach from drainage network, satellite imagery and reflection seismic analyses. Basin Research, 16(2), 165-181.

von Höhnel, L. (1894). The discovery of Lakes Rudolf and Stephanie. London: Longmans and Green.

Wandibba, S. (1981). Some aspects of the Pastoral Neolithic in Kenya. Unpublished paper presented to the Institute of African Studies on 10 February 1981, Nairobi.

Willoughby, P. R. (2006). The evolution of modern humans in Africa: A comprehensive guide. Walnut Creek: Alta Mira.

Wright, D. K. (2011). Frontier animal husbandry in the Northeast and East African Neolithic: A multiproxy paleoenvironmental and paleodemographic study. Journal of Anthropological Research, 67(2), 213-244.

Wright, D. K. (2013). Fits and starts: Why did domesticated animals 'trickle' before they 'splashed' into subSaharan Africa? In M. O. Baldia, T. Perttula, \& D. Frink (Eds.), Comparative archaeology and paleoclimatology: Socio-cultural responses to a changing world (pp. 63-82, BAR International Series 2456). Oxford: Archaeopress.

Wright, D. K., \& Forman, S. L. (2011). Holocene occupation of the Mount Porr strand plain in southern Lake Turkana, Kenya. Nyame Akuma, 76, 47-62.

Wright, D. K., \& Wright, K. D. (2014). Digital Kitambo: Taking the past into the future at the Nairobi National Museum. Johannesburg: Paper presented at the 14th Congress of the Pan-African Association.

Wright, D. K., Forman, S. L., Bloszies, C., \& Hildebrand, E. (2014). To fish or cut bait: Changing subsistence practices in the face of Holocene environmental changes in Turkana, Kenya. Austin, Texas: Paper presented at the Society of American Archaeologists 79th Annual Meeting.

Yamasaki, F., Hamada, C., \& Hamada, T. (1972). Riken natural radiocarbon measurements VII. Radiocarbon, 14(1), 223-238.

Yellen, J. E. (1998). Barbed bone points: Tradition and continuity in Saharan and sub-Saharan Africa. African Archaeological Review, 15(3), 173-198.

Yuretich, R. F. (1979). Modern sediments and sedimentary processes in Lake Rudolf (Lake Turkana) eastern Rift Valley, Kenya. Sedimentology, 26, 313-331.

Yuretich, R. F., \& Cerling, T. E. (1983). Hydrogeochemistry of Lake Turkana, Kenya: Mass balance and mineral reactions in an alkaline lake. Geochimica et Cosmochimica Acta, 47(6), 1099-1109. 